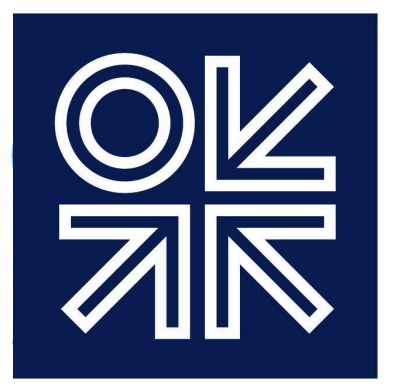

THE OXFORD

INSTITUTE

FOR ENERGY

STUDIES

June 2018

\title{
South Korea's Energy Policy Change and the Implications for its LNG Imports
}


The contents of this paper are the author's sole responsibility. They do not necessarily represent the views of the Oxford Institute for Energy Studies or any of its members.

\author{
Copyright $@ 2018$ \\ Oxford Institute for Energy Studies \\ (Registered Charity, No. 286084)
}

This publication may be reproduced in part for educational or non-profit purposes without special permission from the copyright holder, provided acknowledgment of the source is made. No use of this publication may be made for resale or for any other commercial purpose whatsoever without prior permission in writing from the Oxford Institute for Energy Studies.

ISBN 978-1-78467-113-6

DOI: https://doi.org/10.26889/9781784671136 


\section{Contents}

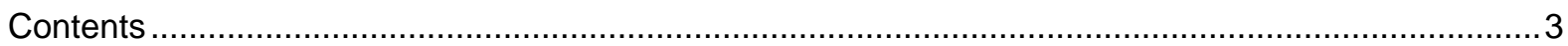

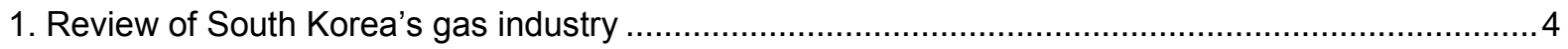

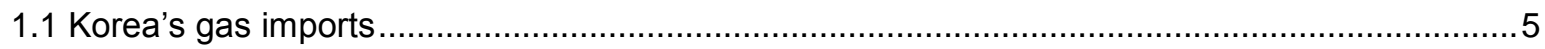

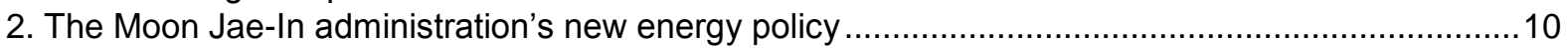

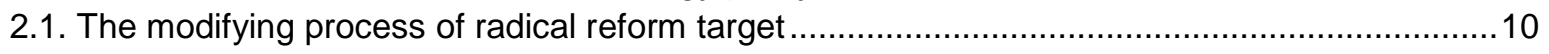

2.2 Compromised gas expansion in MOTIE's new power and gas plan ........................................ 12

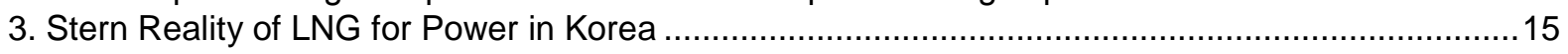

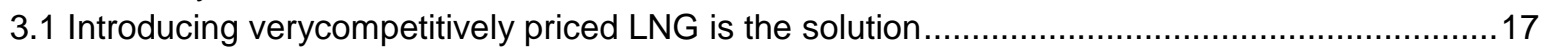

4. The Moon Jae-In administration's northern energy policy and its implications for pipeline gas and

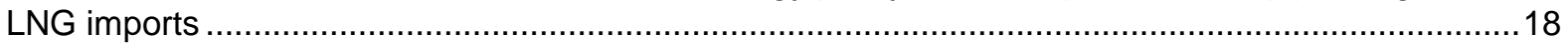

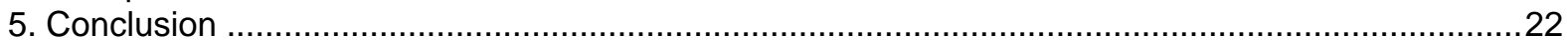

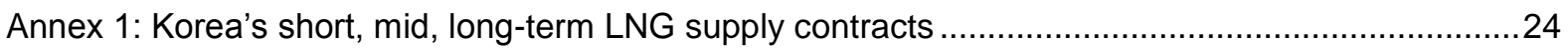

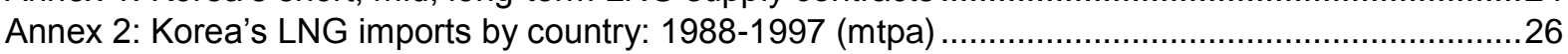

Annex 2.1: Korea's LNG imports by country: 1998-2007 (mtpa) ................................................26

Annex 2.2: Korea's LNG imports by country: 2008-2016 (mtpa) ...............................................26

Annex 3: Korea's monthly LNG imports price: 1988-2007 (US\$/tonne) ............................................27

Annex 3.1: Korea's monthly LNG imports price: 2008-2017 (US\$/tonne) ........................................27

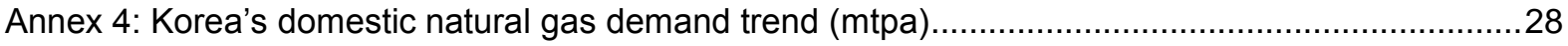

Annex 4.1: Long-term natural gas demand projection: 12th Plan, 2015- 2029 (mtpa) ........................28

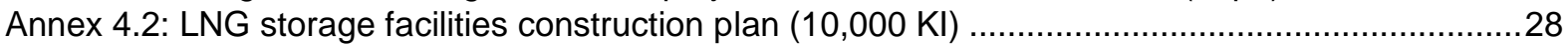

\section{List of Tables}

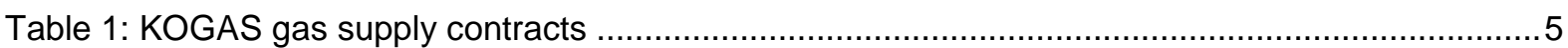

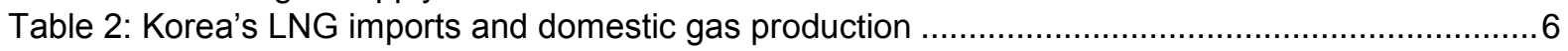

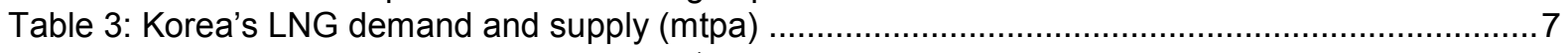

Table 4: International gas price comparison $(\$ / \mathrm{mmbtu})$...................................................................

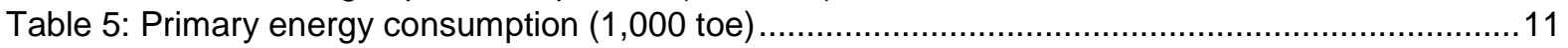

Table 6: Korea's electricity demand projection (GW) .............................................................11

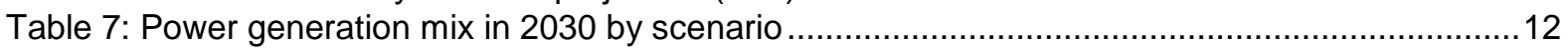

Table 8: Korea's domestic natural gas demand trend: 13th Plan (mt) ..........................................13

Table 9: Long-term natural gas demand projection: 13th Plan, 2018- $2031(\mathrm{mt})$.............................13

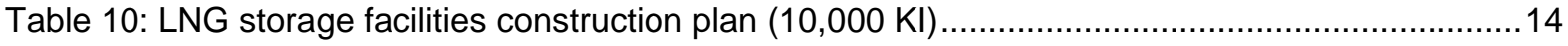

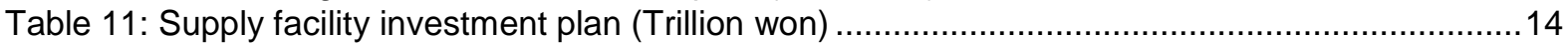

\section{Figures and Maps}

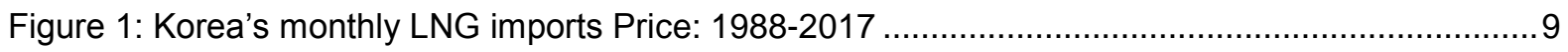

Map 1: Russia's pipeline gas export options/routes for Korean Peninsula ..........................21 
The bold reform of South Korea's energy industry by the Moon Jae-In administration has become a priority for President Moon, who is determined to make sure the radical swing from coal and nuclear towards renewables and LNG for power generation is achieved. ${ }^{1}$ Some are saying that the two earthquakes measuring 5.1 and 5.8 on the Richter scale which occurred on September 12, 2016 in Kyungju have affected President Moon's view on nuclear energy very seriously and fundamentally. The 5.8 magnitude earthquake was the strongest recorded in South Korea, which has consequently suspended the operation of four reactors. ${ }^{2}$ During the last 12 months, however, the priority given to the expansion of renewable energy is overwhelming and the support for the expansion of gas is not as strong as many observers had expected. So far, the gas expansion initiative looks modest at most, and raises the question how far the change to gas will be taken. This paper aims at examining the characteristics of the new Moon Jae-In administration policy and its implications for the gas industry, in particular the expansion of LNG imports. It starts with a review of South Korea's gas industry, and in particular the role of Korea Gas Corporation (KOGAS).

\section{Review of South Korea's gas industry}

South Korea's natural gas industry is dominated by KOGAS. ${ }^{3}$ As of 2017 , it owns three of the four LNG import terminals, the transmission system $(4,790 \mathrm{~km}$ trunkline), more than $90 \%$ of storage capacity and is the sole wholesaler of gas. As of December 2015, there are 34 city gas companies, of which seven are based in the Seoul and Inchon Metropolitan areas, five are in Daejon, Kwangju, Daegu, Busan, and Ulsan, and the remaining 22 are based in local provinces. These city gas companies are responsible for supply to industrial, residential and commercial consumers. Fourteen power companies, with the exception of POSCO (formerly Pohang Iron and Steel Company) and SK E\&S (formerlyK-Power) purchase their gas from KOGAS. ${ }^{4}$ The largest of these is Korea Electric Power Corporation $\left(\mathrm{KEPCO}^{5}\right)$. Under KEPCO, there are five power generation companies $100 \%$ wholly owned by KEPCO- Korea South-east Power $\mathrm{Co}\left(\mathrm{KOEN}^{6}\right)$, Korea Southern Power Co $\left(\mathrm{KOSPO}^{7}\right)$, Korea Midland Power Co Ltd (KOMIPO$\left.{ }^{8}\right)$, Korea Western Power Co Ltd (KOWEPO${ }^{9}$ ), and Korea East-West Power Co Ltd (EWP $\left.{ }^{10}\right)$.

KOGAS was legally formed by the Korean government in1983. Since then, it grew to become the world's largest corporate buyer of LNG (until JERA took over the position ${ }^{11}$ ). KOGAS is listed on the Korean Stock Exchange, and its major shareholders are government entities, such as the central government $(26.9 \%)$, KEPCO $(24.5 \%)$, local governments $(9.6 \%)$ and the Treasury $(6.1 \%)$. As a public enterprise, KOGAS has been and is dominant in the Korean natural gas market. It has expanded the scope of business from import and distribution of natural gas, to exploration and

\footnotetext{
${ }^{1}$ AnjilRaval, "South Korea's energy shift targets increased LNG supply: overhaul of power mix away from coal and nuclear could help balance market”, Financial Times, July 10, 2017. https://www.ft.com/content/fb27d9a4-6547-11e7-9a6693fb352ba1fe?mha5j=e1

${ }^{2}$ https://www.reuters.com/article/us-southkorea-quake-nuclearpower/four-south-korea-nuclear-reactors-suspended-due-toearthquakes-idUSKCN1111X5

${ }^{3}$ http://www.kogas.or.kr/eng/index.do. For Korea's gas industry's transition, see KeunWook Paik, "Chapter 5: Natural Gas Expansion in Korea", in lan Wybrew-Bond and Jonathan Stern, Natural Gas in Asia: The Challenges of Growth in China, India, Japan and Korea (Oxford: Oxford University Press, 2002), pp. 188-229; KeunWook Paik, "Chapter 5: Natural Gas in Korea", in Jonathan Stern. ed., Natural Gas in Asia: The Challenges of Growth in China, India, Japan and Korea (Oxford: Oxford Unviersity Press, 2012), pp. 174-219 (in particular pp. 194-197).

${ }^{4}$ http://www.citygas.or.kr/industry/index.jsp [Unfortunately, as is the case with several other links in this paper, the site referred to here can only be accessed in the Korean language.]

${ }^{5}$ http://home.kepco.co.kr/kepco/EN/A/htmlView/ENACHP00301.do?menuCd=EN010403

${ }^{6}$ www.kosep.co.kr

www.kespo.co.kr

${ }^{8}$ www.komipo.co.kr

${ }^{9}$ www.westernpower.co.kr

${ }^{10}$ www.ewp.co.kr/kor

${ }^{11}$ https://www.reuters.com/article/iapan-iera/update-2-japans-iera-to-integrate-edf-tradings-Ing-business-into-joint-ventureidUSL4N1OE35I; https://www.ft.com/content/4c350efa-d99e-11e7-a039-c64b1c09b482
} 
production projects throughout the world with a participating interest in at least 20 such projects including in Canada, Qatar, Oman, Yemen, Iraq, Myanmar, Indonesia and Russia. ${ }^{12}$ The company's recent focus is on participation in overseas $L N G$ re-gasification terminal projects. ${ }^{13}$

\subsection{Korea's gas imports}

According to the $13^{\text {th }}$ Plan for Long-term Natural Gas Supply and Demand (PLNGSD - "the gas plan") which was announced in early April 2018, in 2012 the top five sources of LNG imported into Korea were: Qatar 28.4\%, Indonesia 20.6\%, Oman 11.4\%, Malaysia 11.3\% and Yemen 7.2\%. In 2017, the ranking was: Qatar $30.8 \%$, Australia $18.6 \%$, Oman $11.3 \%$, Malaysia $10.0 \%$ and Indonesia $9.4 \%$. During the first half of the 2020s, a significant change in this supplier structure looks inevitable as the LNG supply from the US and Russia will gain momentum. MOTIE (the Ministry of Trade, Industry and Energy) has confirmed that Korea aims at diversifying its LNG supply sources. ${ }^{14}$

As shown in Table 1, KOGAS contracts for 8.98 mtpaof LNG (of which $4.92 \mathrm{mtpa}$ is from Qatar and $4.06 \mathrm{mtpa}$ is from Oman), will expire at the end of 2024. It has been argued by Korea's energy newspaper and energy sector NGO (Ms. Yoo-Na Song) that this volume should be allowed to be imported by Gencos under KEPCO, as this would not only serve the purpose of allowing direct imports by state owned companies, but also address the issue of public service that can be easily ignored by the private companies focusing on maximizing profit making. ${ }^{15}$ As opinion is divided, MOTIE will struggle to make the final decision on this matter. (Annex 1 shows the details of all LNG supply contracts to Korea.)

Table 1: KOGAS gas supply contracts

\begin{tabular}{|l|l|l|l|l|}
\hline \multirow{2}{*}{$\begin{array}{l}\text { Producer } \\
\text { country }\end{array}$} & $\begin{array}{l}\text { Project Name } \\
\text { Supplier }\end{array}$ & $\begin{array}{l}\text { Volume } \\
(\mathrm{mt} / \mathrm{y})\end{array}$ & $\begin{array}{l}\text { Contract } \\
\text { period }\end{array}$ & $\begin{array}{l}\text { Delivery } \\
\text { option }\end{array}$ \\
\cline { 2 - 5 } & RasGas & 4.92 & $1999-2024$ & FOB \\
\cline { 2 - 5 } & RasGas II & $2.00+$ mid-term V & $2012-2032$ & DES \\
\cline { 2 - 5 } & RasGas III & 2.10 & $2007-2026$ & DES \\
\cline { 2 - 5 } & GLNG & $3.00+$ option 0.5 & $2015-2035$ & FOB \\
\cline { 2 - 5 } & Prelude & 3.64 & $2013-2038$ & DES \\
\cline { 2 - 5 } & Total & 2.00 & $2014-2031$ & DES \\
\hline Malaysia & MLNG III & $1.50+$ option 0.5 & $2008-2028$ & DES \\
\hline Indonesia & Badak V & 1.00 & $1998-2017$ & FOB \\
\hline Oman & OLNG & 4.06 & $2000-2024$ & FOB \\
\hline Yemen & YLNG & 2.00 & $2008-2028$ & FOB \\
\hline Russia & Sakhalin II & 1.50 & $2008-2028$ & FOB \\
\hline US & Sabine Pass & 2.80 & $2017-2037$ & FOB \\
\hline Shell & Portfolio & 3.64 & $2013-2038$ & DES \\
\hline Korea & DongHae gas & 0.40 & $2004-2018$ & PNG \\
\hline Total & & $28.56+$ option 1.0 & & \\
\hline
\end{tabular}

Note: DES means Delivered Ex-Ship; PNG means pipeline gas.

Source: KOGAS and Korea Gas Union (2017)

\footnotetext{
${ }^{12}$ http://www.kogas.or.kr/eng/selectBbsNttView.do?key=1581\&searchBbsNo=\&orgBbs No=442\&bbs No=442\&nttNo=35400\&sear chCtgry=\&searchCnd=all\&searchKrwd=\&pagelndex $=1$ \&integrDeptCode $=($ Kogas, Results of FY 2017).

${ }^{13}$ http://www.kogas.or.kr/eng/contents.do?key=2170

${ }^{14}$ https://www.platts.com/latest-news/natural-gas/singapore/s-korea-revises-up-Ing-demand-forecasts-on-plan-27952043

${ }^{15}$ http://www.energy-news.co.kr/news/articleView.html?idxno=52610; http://www.energy-

news.co.kr/news/articleView.html?idxno=51676
} 
In 2017, Korea imported 37.6 million tonnes of LNG, an increase of $12.4 \%$ on 2016 , making it the second highest year for LNG imports on record. The average price Korea paid for LNG during January - October 2017 was up by $14 \%$ year on year at US $\$ 8.03 / \mathrm{mmbtu}$, and total expenditure was US\$ 3.5 billion more than in 2016. However, the fall in price between 2014 and 2017 meant that Korea paid roughly half the US\$31 billion spent on importing LNG in 2014 for a similar volume. Due to a growing diversity in LNG imports in recent years, Korea's reliance on Qatar is falling while Australia's share of the mix has increased markedly, and it became one of the biggest importers of US LNG, receiving almost 2 million tonnes in $2017 .{ }^{16}$

Table 2: Korea's LNG imports and domestic gas production

\begin{tabular}{|l|c|c|c|l|c|c|c|}
\hline Year & $\begin{array}{c}\text { Import } \\
\text { Volume } \\
(\mathrm{mt} / \mathrm{y})\end{array}$ & $\begin{array}{c}\text { Amount } \\
(\mathrm{US} \$ \\
\text { million})\end{array}$ & $\begin{array}{c}\mathrm{DP}^{*} \\
(\mathrm{mt} / \mathrm{y})\end{array}$ & Year & $\begin{array}{c}\text { Import } \\
\text { Volume } \\
(\mathrm{mt} / \mathrm{y})\end{array}$ & $\begin{array}{c}\text { Amount } \\
(\mathrm{US} \$ \\
\text { million})\end{array}$ & $\begin{array}{c}\mathrm{DP} \\
(\mathrm{mt} / \mathrm{y})\end{array}$ \\
\hline 1988 & 1.90 & 322.7 & - & 2003 & 19.31 & 5081.9 & - \\
\hline 1989 & 2.01 & 346.9 & - & 2004 & 21.78 & 6551.6 & 0.16 \\
\hline 1990 & 2.24 & 495.5 & - & 2005 & 22.32 & 8646.5 & 0.40 \\
\hline 1991 & 2.49 & 485.2 & - & 2006 & 25.26 & 11924.9 & 0.35 \\
\hline 1992 & 2.99 & 561.7 & - & 2007 & 25.57 & 12653.3 & 0.27 \\
\hline 1993 & 4.46 & 781.5 & - & 2008 & 27.26 & 19806.1 & 0.18 \\
\hline 1994 & 6.00 & 961.5 & - & 2009 & 25.82 & 13875.0 & 0.38 \\
\hline 1995 & 6.76 & 1275.3 & - & 2010 & 32.60 & 17006.0 & 0.41 \\
\hline 1996 & 9.26 & 1878.4 & - & 2011 & 36.68 & 23859.3 & 0.35 \\
\hline 1997 & 11.47 & 2295.9 & - & 2012 & 36.18 & 27364.5 & 0.33 \\
\hline 1998 & 10.19 & 1549.3 & - & 2013 & 39.88 & 30645.1 & 0.36 \\
\hline 1999 & 12.28 & 1972.6 & - & 2014 & 37.11 & 31402.5 & 0.27 \\
\hline 2000 & 15.24 & 3882.3 & - & 2015 & 33.37 & 18779.1 & 0.14 \\
\hline 2001 & 15.32 & 3989.8 & - & 2016 & 33.45 & 12170.0 & 0.12 \\
\hline 2002 & 17.99 & 4120.2 & - & $2017 \mathrm{E}^{* *}$ & 37.60 & & \\
\hline
\end{tabular}

Note: *Domestic Production; ${ }^{* *} 2017$ volume 37.6 million tonnes is reported by Interfax Natural Gas Daily, January 29, 2018.

Source: http://www.kesis.net/sub/subChart.jsp?report id=7010102\&reportType $=0$ (This KESIS - Korea Energy Statistical information System - site is from KEEl's website) 
Table 3: Korea's LNG demand and supply (mtpa)

\begin{tabular}{|l|c|c|c|c|c|c|}
\hline & Imports & Consump-tion & $\mathrm{PG}^{*}$ & $\mathrm{GM}$ & Others & Stocks \\
\hline 1990 & 2.291 & 2.329 & 1.741 & 0.576 & 0.012 & 0.046 \\
\hline 1995 & 7.060 & 7.087 & 3.562 & 3.417 & 0.108 & 0.103 \\
\hline 2000 & 14.578 & 14.557 & 4.018 & 9.528 & 0.340 & 0.591 \\
\hline 2005 & 22.341 & 23.350 & 7.674 & 14.077 & 0.229 & 0.959 \\
\hline 2010 & 32.603 & 33.083 & 13.616 & 17.522 & 0.213 & 2.667 \\
\hline 2011 & 36.685 & 35.603 & 12.999 & 18.255 & 0.214 & 3.323 \\
\hline 2012 & 36.184 & 38.485 & 14.087 & 19.588 & 0.200 & 1.840 \\
\hline 2013 & 39.876 & 40.278 & 15.025 & 19.596 & 0.195 & 2.237 \\
\hline 2014 & 37.107 & 36.636 & 13.719 & 18.180 & 0.144 & 3.182 \\
\hline 2015 & 33.366 & 33.446 & 13.033 & 16.929 & 0.073 & 3.034 \\
\hline
\end{tabular}

Note: PG means power generation: * includes District Heating; GM means Gas Manufacturing (City Gas), Source: http://www.kesis.net/sub/subChart.jsp?report id=7010102\&reportType $=0$ (This KESIS site is from KEEl's website)

According to the EIA, Korea imported about $1.99 \mathrm{mt}$ (88.2 bcf) from the US during January - October 2017, a 773\% increase on 2016. The largest importer of US LNG was Mexico with 126 bcf. In 2012 , KOGAS signed a long-term contract to import $2.8 \mathrm{mtpa}$ from Sabine Pass, starting from 2017.17 Including the $2.2 \mathrm{mtpa}$ contracted from 2019 by SK E\&S ${ }^{18}$ the total US LNG supply volume is 5.0 mtpa. If Hanyang Corp's MOU with Delfin LNG in late June 2017 for $1.5 \mathrm{mtpa}$ becomes a contract, ${ }^{19}$ the figure will be at least $6.5 \mathrm{mtpa}$. It is worth noting that around 2012 Korea was floating a target figure of 8.0 mtpa for the supply volume from the US. ${ }^{20}$ This big increase in US LNG supply to Korea is opening a debate on supply security and price competitiveness issues. Both Japan and Korea used to bear an LNG price burden under the name of energy supply security, but nowadays both gas importers are more conscious of price competitiveness.

The so-called Asian premium has become too big a burden for Northeast Asian gas consumers. The March 2011 Fukushima disaster and consequently the astronomical increase in the trade deficit during 2012 and 2016 caused by the rapid increase of LNG imports (see Table 4) had reminded Japan of the need to reduce the financial burden of LNG imports. ${ }^{21}$ In 2014, Japan spent a record 7.85 trillion yen (US $\$ 63.3$ billion) on 88.51 million tonnes of the fuel. ${ }^{22}$ In the wake of the Fukushima earthquake, Japan's METI has organised annual LNG producer and consumer conferences since 2012 to explore ways of reducing the financial burden of LNG imports23, but LNG producers and suppliers were not so sympathetic towards the financial pain Asian gas consumers had to bear.

\footnotetext{
${ }^{17} J u n g ~ S u k-y e e, ~ " 2$ nd Largest Importer of US LNG", Business Korea, January 22, 2018. http://www.businesskorea.co.kr/english/news/industry/20340-2nd-largest-importer-us-Ing-s-korea-imported-eight-times-moreIng-us-last-year

${ }^{18} \mathrm{https}$ ://www.reuters.com/article/southkorea-gas-usa/sk-es-imports-south-koreas-first-u-s-shale-gas-spot-cargo-sourcesidUSL4N1FA2TG

19“여수묘도에 LNG 허브터미널탄생예고” (July 19, 2017)

http://m.energy-news.co.kr/news/articleView.html?idxno=49003

${ }^{20}$ Keun-Wook Paik with GladaLahn and Jens Hein,"Through the Dragon Gate?: A Window of Opportunity for Northeast Asian Gas Security", Chatham House, EER BP 12/05 (Energy, Environment and Resource Programme Briefing Paper, December 2012), p.10.

${ }^{21}$ According to METI's data, the trade deficits in 2011, 2012, 2013, and 2014 were 4.4 trillion yen, 8.2 trillion yen, 13.7 trillion yen, and 9.1 trillion yen respectively. See Jun Arima, Japan's Mid-Long Term Climate Strategy, presented at 2017 WEC International Energy Symposium, organized by Korea Energy Foundation, November 22, 2017 ;

https://www.japantimes.co.jp/news/2017/01/25/business/\%C2\%A54-trillion-japan-saw-first-trade-surplus-six-years-2016-amidimport-drop/\#.WxkeN5CG99A

${ }^{22}$ https://www.reuters.com/article/energy-japan-imports-Ing-idUSL3N10300T20150723

${ }^{23}$ http://www.Ing-conference.org/english/
} 
This is what the Korean authorities are really worrying about, as the country has no effective leverage to reduce the level of imported LNG prices. In 2015, it is why MOTIE's gas division director Ho-Hyun Lee took the initiative to promote Korea-Japan-China's LNG cooperation for the first time in the history of the Northeast Asian region. Mr. $\mathrm{H}-\mathrm{H}$ Lee understood that the common interest lay in reducing the price of burden of LNG imports and there was a consensus on this matter among the three LNG buyers. The result of his initiative was Clause 19 of the joint declaration of the trilateral summit in Seoul on November 1, 2015.24

"We reaffirmed the necessity of trilateral energy cooperation in achieving sustainable growth and co-prosperity of Northeast Asia. In this regard, we will strengthen our cooperation on LNG to enhance the liquidity and efficiency of the LNG market in Northeast Asia".

MOTIE's $13^{\text {th }}$ gas plan confirmed that during the last five years there were 71 LNG swap deals, 64 between Korea and Japan, and 7 between Korea and China. The big difference between Korea's LNG cooperation with Japan and China strongly indicates the potential (or obstacle) for LNG cooperation between Korean and China. If very well co-ordinated LNG cooperation between Korea, Japan and China is implemented, it could lead to an Asian Gas Consumers' Alliance that will explore the options for reducing the LNG import price more effectively.

Table 4: International gas price comparison $(\$ / \mathrm{mmbtu})$

\begin{tabular}{|c|c|c|c|c|c|}
\hline & Korea CIF & Japan CIF & German* & U.K. & $\begin{array}{c}\text { US } \\
\text { Henry Hub }\end{array}$ \\
\hline 1985 & & 5.23 & & & \\
\hline 1986 & 2.77 & 4.10 & 3.93 & & \\
\hline 1989 & 3.30 & 3.28 & 2.00 & & 1.70 \\
\hline 1991 & 3.56 & 3.99 & 3.23 & & 1.49 \\
\hline 1993 & 3.35 & 3.52 & 2.51 & & 2.12 \\
\hline 1995 & 3.37 & 3.46 & 2.43 & & 1.69 \\
\hline 1996 & 3.80 & 3.66 & 2.50 & 1.87 & 2.76 \\
\hline 1998 & 2.83 & 3.05 & 2.33 & 1.86 & 2.08 \\
\hline 2000 & 5.03 & 4.72 & 2.91 & 2.71 & 4.23 \\
\hline 2001 & 4.84 & 4.64 & 3.67 & 3.17 & 4.07 \\
\hline 2002 & 4.24 & 4.27 & 3.21 & 2.37 & 3.33 \\
\hline 2003 & 4.98 & 4.77 & 4.06 & 3.33 & 5.63 \\
\hline 2004 & 5.64 & 5.18 & 4.30 & 4.46 & 5.85 \\
\hline 2005 & 6.86 & 6.05 & 5.83 & 7.38 & 8.80 \\
\hline 2006 & 9.21 & 7.14 & 7.87 & 7.87 & 6.76 \\
\hline 2007 & 9.46 & 7.73 & 7.99 & 6.01 & 6.95 \\
\hline 2008 & 14.26 & 12.55 & 11.60 & 10.79 & 8.85 \\
\hline 2009 & 9.53 & 9.06 & 8.53 & 4.85 & 3.89 \\
\hline 2010 & 10.15 & 10.91 & 8.03 & 6.56 & 4.39 \\
\hline 2011 & 12.64 & 14.73 & 10.49 & 9.04 & 4.01 \\
\hline 2012 & 14.64 & 16.75 & 10.93 & 9.46 & 2.76 \\
\hline 2013 & 14.77 & 16.71 & 10.73 & 10.64 & 3.71 \\
\hline 2014 & 16.31 & 16.33 & 9.11 & 8.25 & 4.35 \\
\hline 2015 & 10.56 & 10.31 & 6.72 & 6.53 & 2.60 \\
\hline 2016 & 6.86 & 6.94 & 4.93 & 4.69 & 2.46 \\
\hline
\end{tabular}

Note: Average German import price, Source: BP Statistical Review of World Energy, June 2017. 

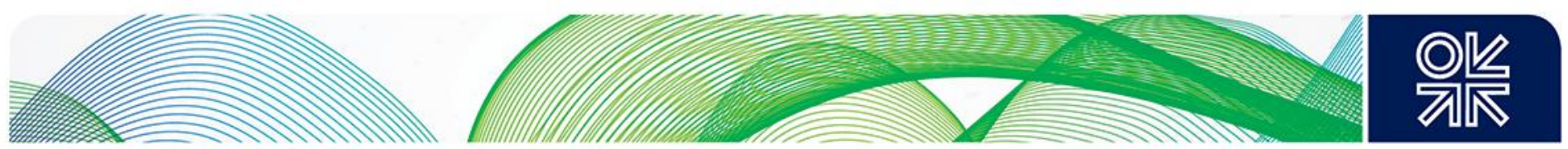

Figure 1: Korea's monthly LNG imports Price: 1988-2017

Total Import Value (Million USD) Unit Cost (USD / Tonne)

4200 복만 USD

1680 USD/ton

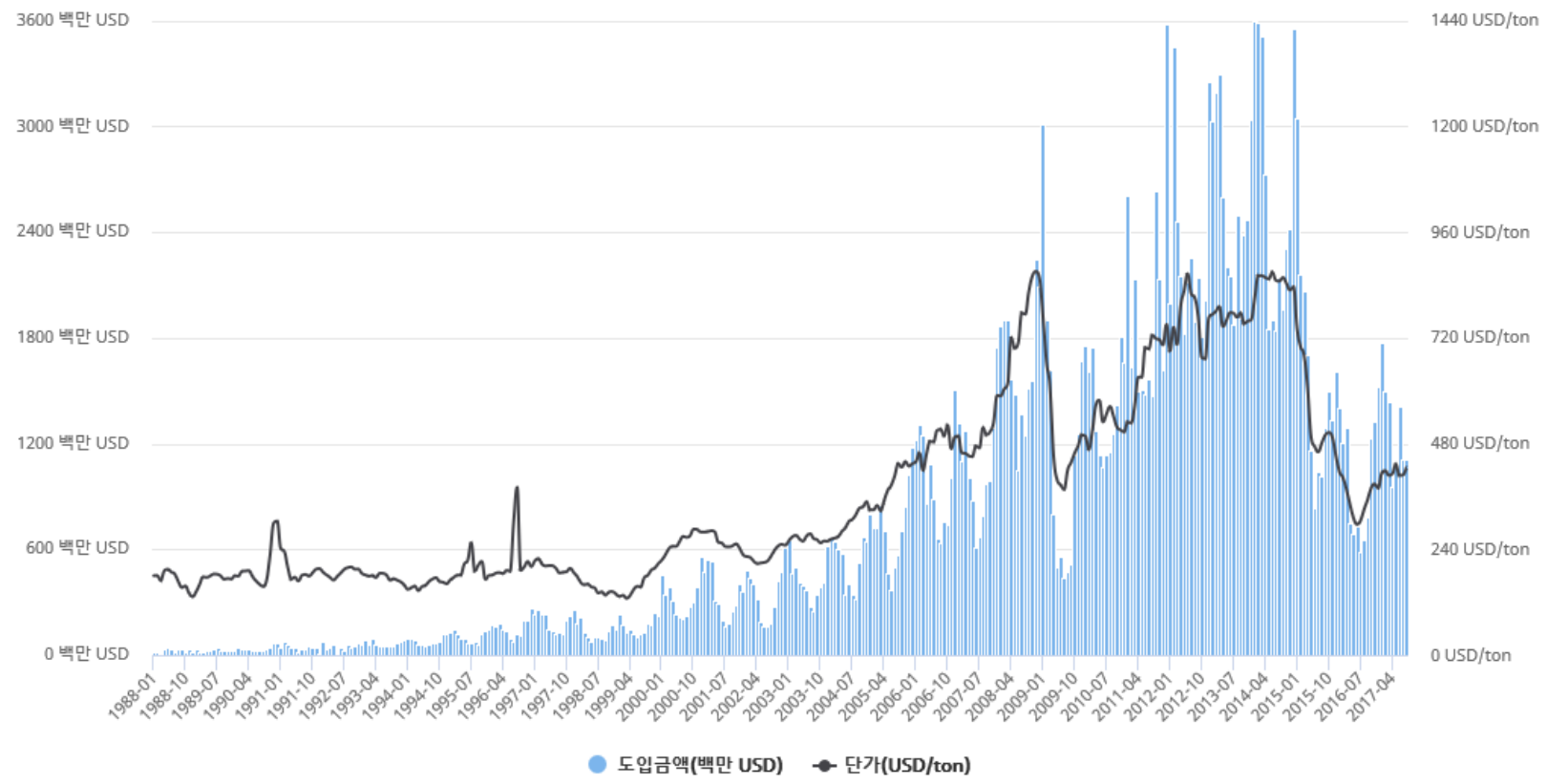

Source: http://www.kesis.net/sub/subChart.jsp?report id=7050100\&reportType $=0$

(accessed from KEEI Energy Data basis website, on December 12, 2017)

In December 2017Jonathan Stern questioned the logic of suppliers who are waiting for a tightening in the global gas market to encourage prices back to a level that can incentivise new investment, especially in greenfield LNG projects. A key assertion is that the disparity between the likely cost of new LNG projects and the affordable price of gas in many future growth markets will need to be closed by a focus on cost reduction by project developers, rather than by a hope that higher prices and rising demand will be sustainable at the same time.He concluded that a return to internationally traded gas prices above $\$ 8 / \mathrm{mmbtu}$ would make gas unaffordable in many potential new gas markets, and uncompetitive with domestic (and imported) coal in both low-income countries and high-income countries which lack either environmental regulation or carbon-related taxation. At these price levels gas will also become progressively less competitive with wind and solar (backed by battery storage) which will further contribute to demand destruction.In short, the key to gas fulfilling a potential role as a 'transition fuel' over the next two decades is that it must be delivered to high-income countries below $\$ 8 / \mathrm{mmbtu}$, and to low-income countries below $\$ 6 / \mathrm{mmbtu}$ (and ideally closer to $\$ 5 / \mathrm{mmbtu}$ ). The major challenge to the future of gas, he said, will be to ensure that it does not become (and in many low-income countries remain) unaffordable and/or uncompetitive, long before its emissions make it unburnable. ${ }^{25}$

Without expanding the consensus among Asian gas consumers, affordable gas for the emerging economies will not become available that easily. It is worth noting that a price review arbitration case between KOGASand North West Shelf, Australia's first and biggest LNG exporter, is not insignificant as it could set an important precedent and open the floodgates for future contractual renegotiations 

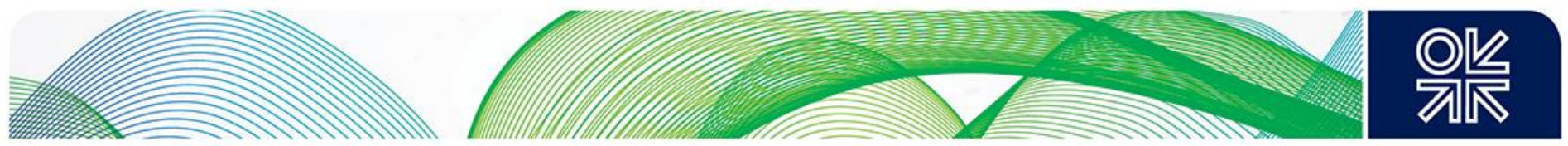

and pricing reviews in the global LNG industry, with potential implications for all its stakeholders. ${ }^{26}$ This case is a confirmation that both seller and buyer are very conscious of the implications of the pricesettlement.

What sort of steps the Korean government will take to minimize the gas price burden is a very difficult question to answer. Another very difficult question is whether the monopoly position of KOGAS will be protected by the government. The reason MOTIE's $13^{\text {th }}$ gas plan did not take the bold step towards the significant expansion of gas in Korea's energy mix lies in MOTIE's conventional thinking that Korea has to be the passive receipient of LNG supply options rather than making a bold initiative that can introduce very competitively priced LNG supply sources, based on LNG cooperation among Asian gas consumers. Even though the Moon Jae-In administration has been exploring the option of importing gas from Russia, and this initiative was not conceivable under the Park Geun-Hye administration, it is too early to make any meaningful verdict on the initiative.

\section{The Moon Jae-In administration's new energy policy}

\subsection{The modifying process of radical reform target}

During the recent presidential campaign, Presidential candidate Moon Jae-In strongly indicated that his government would increase the share of gas for power generation to about $27 \%$ by 2030 , from $19 \%$ in 2017 , and that of renewable energy from the mere $5 \%$ to $20 \%$ by 2030 . However, independent research consultancy Energy Aspects has pointed out that the change could be time-consuming, noting that rather than gas, Korea turned to new coal plants to offset the loss of nuclear generation. Since January 2016, Korea has added over 15 GW of new power generation capacity, 8 GW of which was coal-based - nearly double the 4.6 GW of new gas-based capacity. Over 2017, coal-based generation was up by $15 \mathrm{TWh}(12 \%)$ with gas only increasing by $0.63 \mathrm{TWh}(1 \%)$. It added that while new government policies will take some time to have an impact, in the period to 2025 the policies are more likely to stimulate an increase in renewables and only gradually improve utilisation of gas plants. For gas to play a bigger role, the commodity needs to be cheaper. Key to getting this is power and gas market liberalisation, a policy shift that we are yet to hear about. ${ }^{27}$ The Energy Aspect analysis identifies what is the main obstacle to Korea's gas expansion.

In May 2017, Moon Jae-In's new administration put environmental protection at the heart of energy policymaking in response to mounting anxieties about air pollution and nuclear safety. This policy shift from coal and nuclear towards renewables and LNG for power generation gave an impression that it could help expand the use of LNG significantly. Chong Zhi Xin, principal Asia LNG analyst at energy consultancy Wood Mackenzie said: "If there are no new nuclear and coal plants, the potential LNG imports could be 46-49 (mtpa) depending on the success of the renewable targets". ${ }^{28}$ However, there are doubts as to how far the swing can go. As shown in Table 5, the trend of ever-growing coal consumption during 2000-2015 signals the swing may not be as big as President Moon's administration is hoping for.

\footnotetext{
${ }^{26}$ Abache Abreu, "Stakes high in Kogas-NWS LNG price dispute", Platts, February 22, 2018. https://www.platts.com/latestnews/natural-gas/singapore/stakes-high-in-kogas-nws-Ing-price-dispute-26896507

${ }^{27}$ Trevor Sikorski, "South Korea - changing direction", Energy Aspects, September 22, 2017. https://www.energyaspects.com/publications/view/2017-09-22-natural-gas-natural-gas-global-Ing-south-korea-changingdirection

${ }^{28}$ Jane Chung, "South Korea plans energy U-turn away from coal, nuclear", Reuters, June 4, 2017. https://www.reuters.com/article/us-southkorea-politics-energy/south-korea-plans-energy-u-turn-away-from-coal-nuclearidUSKBN18V0EH ; https://www.platts.com/latest-news/natural-gas/seoul/analysis-south-korea-headed-for-Ing-import-boost$\underline{27826809 .}$.
} 
Table 5: Primary energy consumption (1,000 toe)

\begin{tabular}{|l|c|c|c|c|c|}
\hline & 1981 & 1990 & 2000 & 2010 & 2015 \\
\hline Coal & 14,478 & 19,855 & 19,847 & 29,164 & 34,921 \\
\hline & $37.2 \%$ & $26.4 \%$ & $13.2 \%$ & $14.9 \%$ & $16.0 \%$ \\
\hline Oil & 18,912 & 45,252 & 93,596 & 100,381 & 107,322 \\
\hline & $48.6 \%$ & $60.3 \%$ & $62.5 \%$ & $51.3 \%$ & $49.1 \%$ \\
\hline Gas & 23 & 1,011 & 12,561 & 21,640 & 22,115 \\
\hline Electricity & $0.1 \%$ & $1.3 \%$ & $8.4 \%$ & $11.1 \%$ & $11.1 \%$ \\
\hline & 3,046 & 8,117 & 20,600 & 37,338 & 41,594 \\
\hline Heat & $7.8 \%$ & $10.8 \%$ & $13.7 \%$ & $19.1 \%$ & $19.0 \%$ \\
\hline & - & 75 & 1,119 & 1,718 & 1,559 \\
\hline Renewable & 2,492 & 797 & 2,130 & 5,346 & 11,096 \\
\hline & $6.4 \%$ & $1.1 \%$ & $1.4 \%$ & $2.7 \%$ & $5.1 \%$ \\
\hline Total & 38,952 & 75,107 & 149,852 & 195,597 & 216,608 \\
\hline & $100.0 \%$ & $100.0 \%$ & $100.0 \%$ & $100.0 \%$ & $100 \%$ \\
\hline
\end{tabular}

Source: KEEI, Yearbook of Energy Statistics 2016, pp. 18-19. http://www.kesis.net/sub/sub 0003.jsp

Until recently, South Korea generated two-thirds of its electricity from coal-fired power plants and nuclear reactors, with the government in recent years using tax incentives to create abundant and affordable power supply after blackouts had become a common occurrence. That is, coal and nuclear power were the base load power and the cornerstone of Korea's power generation. However, the new administration has committed to stop the construction of new coal and nuclear plants. As shown in Table 6, the two drafts of the $8^{\text {th }}$ Basic Plan for Long-term Electricity Supply and Demand (BPLESD, the electricity plan) released in July and September 2017 project that 2030 electricity demand will be much smaller than that in the $7^{\text {th }}$ electricity plan, around 101-102 GW compared with 113GW.

Table 6: Korea's electricity demand projection (GW)

\begin{tabular}{|l|c|c|c|}
\hline & $7^{\text {th }}$ Plan Actual & $8^{\text {th }}$ Plan $1^{\text {st }}$ Draft & $8^{\text {th }}$ Plan 2 nraft \\
\hline 2020 & 97.3 & 90.9 & 90.3 \\
\hline 2022 & 101.8 & 94.1 & 93.3 \\
\hline 2024 & 105.2 & 96.9 & 95.7 \\
\hline 2026 & 108.0 & 99.1 & 97.6 \\
\hline 2030 & 110.6 & 100.6 & 99.1 \\
\hline 2031 & 113.2 & 101.9 & 100.5 \\
\hline
\end{tabular}

Note: $1^{\text {st }}$ Draft revealed on July 13, 2017, and $2^{\text {nd }}$ Draft revealed on September 15, 2017.

Source: http://www.energy-news.co.kr/news/articleView.html?idxno=49991 
Table 7: Power generation mix in 2030 by scenario

\begin{tabular}{|l|c|c|c|c|}
\hline \multirow{2}{*}{ Category } & \multicolumn{3}{|c|}{ S1 } & \multicolumn{2}{c|}{ S2 } \\
\cline { 2 - 5 } & \multicolumn{3}{|c|}{ In $2030: 8^{\text {th }}$ plan demand } \\
\cline { 2 - 5 } & $\begin{array}{c}\text { Maintaining the basic direction of } \\
\text { the } 7^{\text {th }} \text { plan* }\end{array}$ & \multicolumn{2}{c|}{$\begin{array}{c}\text { Nuclear and Coal } \\
\text { Phase-out }\end{array}$} \\
\hline Nuclear & 262,522 & $\begin{array}{c}\text { Ratio } \\
(\%)\end{array}$ & $\begin{array}{c}\text { Generation } \\
(\mathrm{GWh})\end{array}$ & $\begin{array}{c}\text { Ratio } \\
(\%)\end{array}$ \\
\hline Coal & 241,142 & 41.3 & 134,048 & 21.2 \\
\hline Gas & 54,051 & 38.0 & 220,349 & 34.8 \\
\hline Renewables & 74,190 & 8.50 & 147,372 & 23.3 \\
\hline Other & 3,024 & 11.7 & 129,007 & 20.4 \\
\hline Total & 634,929 & 0.50 & 1,833 & 0.30 \\
\hline
\end{tabular}

Note: Maintaining the power capacity mix of the $7^{\text {th }}$ plan.

Source: Myeongdeok Park, "New Power Generation Mix and Policy Direction", presented at 2017 Korea-ChinaJapan Energy Conference for the $31^{\text {st }}$ Anniversary of KEEl, titled "Toward a New Energy Paradigm: Challenges and Policy Direction of Northeast Asia Countries, held in Seoul, September 11, 2017.

The draft MOTIE plan in early September 2017 did include plans to close seven old coal-fired plants by 2022, and halt construction of new coal and nuclear generators. ${ }^{29}$ That is, the world's fifth-largest thermal coal importer and the nation with the sixth-biggest fleet of nuclear reactors is overhauling the country's energy mix, prompting a reappraisal of the country's LNG demand assumptions. As shown in Table 7, according to KEEl's calculation, under S2, compared with S1, about $12.55 \mathrm{mt}$ of additional LNG demand is generated in 2030. And about 17 million tonnes of additional $\mathrm{CO}_{2}$ will be emitted in 2030. However, MOTIE's final electricity and gas plans in December 2017 and April 2018 were not bold enough to support the strengthened gas share in the energy mix.

\subsection{Compromised gas expansion in MOTIE's new power and gas plan}

MOTIE prepares a long-term electricity and natural gas supply anddemand plan every two years. The $7^{\text {th }}$ electricity plan and $12^{\text {th }}$ gas plan were annnounced in July 2015 and in December 2015 respectively. The latest plans, the $8^{\text {th }}$ electricity plan and the $13^{\text {th }}$ gas plan were announced in December $2017^{30}$ and April $2018^{31}$ respectively. Under the $8^{\text {th }}$ electricity plan, which reflects environmental and safety factors in addition to objectives of stable power supply and economic efficiency, Korea will produce more power from renewable energy sources and natural gas, while gradually reducing its reliance on coal and nuclear power, all based on forecast power demand over the next 15 years until 2031. Peak electricity demand in 2030 is forecast at $100.5 \mathrm{GW}, 11 \%$ down on the forecast of $113.2 \mathrm{GW}$ made in the $7^{\text {th }}$ plan. The blueprint calls for further reduction in the expected peak demand by $12.3 \%$, or $14.2 \mathrm{GW}$. The target reserve margin for 2030 -thecapacity in excess of forecast peak demand - is $22 \%$ of peak demand, so that there is a requirement for installed capacity in 2030 of $122.6 \mathrm{GW} .{ }^{32}$

MOTIE elaborated that power generation facilities with a combined capacity of $4.3 \mathrm{GW}$ need to be newly added to existing and already planned facilities with a capacity of $118.3 \mathrm{GW}$. The new

\footnotetext{
${ }^{29}$ Jane Chung, "S. Korea eyes lifting LNG, renewable capacity by a tenth in clean power drive", Reuters, September 6, 2017. http://www.reuters.com/article/us-usa-trump-congress/trump-meets-congressional-leaders-amid-fight-over-debt-limitimmigration-idUSKCN1BH24F ; Clyde Russell, "South Korea pivot to LNG, drives nail in coal's coffin", Reuters, September 7 , 2017. https://www.reuters.com/article/column-russell-Ing-asia/column-south-korea-pivot-to-Ing-drives-nail-in-coals-coffin-russellidUSL4N1LO1WB

${ }^{30}$ Ministry announces $8^{\text {th }}$ Basic Plan for Electricity Supply and Demand (December 14, 2017). http://english.motie.go.kr/en/pc/pressreleases/bbs/bbsView.do?bbs cd $n=2 \& b b s$ seq $n=605$ ${ }^{31}$ http://www.gasnews.com/news/articleView.html?idxno=82317

${ }^{32} \mathrm{lbid}$.
} 
generation facilities will be LNG-based power stations and pumped-storage hydroelectric facilities. Between 2017 and 2030, the installed capacity of renewables would increase to $58.5 \mathrm{GW}$ from the current $11.3 \mathrm{GW}$ with the growth mainly coming from solar and wind power. The total capacity of LNG-based power plants would expand to $47.5 \mathrm{GW}$ from $37.4 \mathrm{GW}$, and that of coal-fired power plants to $39.9 \mathrm{GW}$ from $36.8 \mathrm{GW}$. Meanwhile, the installed capacity of nuclear power generation would contract to $20.4 \mathrm{GW}$ from $22.5 \mathrm{GW}$ as five new reactors would enter operation and 11 aging reactors would be taken offline during the period. ${ }^{33}$

According to the $13^{\text {th }}$ gas plan, Korea's domestic gas demand has increased from $1.61 \mathrm{mt}$ in 1987 to $36.81 \mathrm{mt}$ in 2017, with the average growth rate of $11 \%$. In 2013 demand reached the record level of $40.08 \mathrm{mt}$, but then declined and has been rising again since 2016. The $13^{\text {th }}$ gas plan's main assumption is that the annual economic growth rate and the population increase rate during 2018-31 will be $2.4 \%$ and $0.2 \%$ respectively. As shown in table 9 , the total forecast gas demand will rise from $36.46 \mathrm{mt}$ in 2018 to $40.49 \mathrm{mt}$ in 2031 , anaverage annual growth rate of $0.81 \%$. The city gas demand will grow at $1.24 \%$ /year from $19.94 \mathrm{mt}$ in 2018 , to $23.4 \mathrm{mt}$, while gas for power generationwill grow at $0.26 \%$ /year from $16.52 \mathrm{mt}$ in 2018 to $17.09 \mathrm{mt}$ in 2031, a significant increase on the $12^{\text {th }}$ gas supply and demand plan forecast of $9.48 \mathrm{mt}$ in 2029.

Table 8: Korea's domestic natural gas demand trend: $13^{\text {th }}$ Plan (mt)

\begin{tabular}{|l|c|c|c|c|c|c|c|c|}
\hline & 1987 & 1997 & 2002 & 2009 & 2017 & \multicolumn{3}{|c|}{ annual growth rate } \\
\cline { 1 - 4 } & & & & & & $87-17$ & $87-02$ & $03-17$ \\
\hline CG & 0.07 & 5.77 & 11.19 & 15.63 & 19.51 & $20.3 \%$ & $39.6 \%$ & $3.5 \%$ \\
\hline PG & 1.54 & 5.38 & 6.51 & 10.04 & 17.30 & $8.4 \%$ & $10.1 \%$ & $7.3 \%$ \\
\hline Total & 1.61 & 11.15 & 17.70 & 26.04 & 36.81 & $11.0 \%$ & $17.3 \%$ & $6.1 \%$ \\
\hline
\end{tabular}

Note: $C G$ means city gas and $P G$ means power generation

Source: MOTIE, 13 ${ }^{\text {th }}$ Gas Supply and Demand Plan (2018-2031), announced in April 2018.

Table 9: Long-term natural gas demand projection: $13^{\text {th }}$ Plan, 2018- 2031 (mt)

\begin{tabular}{|l|c|c|c|c|c|}
\hline \multirow{2}{*}{ Year } & \multicolumn{3}{|c|}{ City Gas } & PG & Total \\
\cline { 2 - 4 } & Residential/general & Industrial & Sub-total & & \\
\hline 2018 & 11.85 & 8.09 & 19.94 & 16.52 & 36.46 \\
\hline 2024 & 12.31 & 8.86 & 21.17 & 12.94 & 34.11 \\
\hline 2031 & 13.29 & 10.11 & 23.40 & 17.09 & 40.49 \\
\hline $18-31$ AG & $0.89 \%$ & $1.73 \%$ & $1.24 \%$ & $0.26 \%$ & $0.81 \%$ \\
\hline
\end{tabular}

Note: PG means power generation; A means actual; AG means annual growth rate

Source: MOTIE, April 2018. 
Table 10: LNG storage facilities construction plan $(10,000 \mathrm{KI})$

\begin{tabular}{|l|c|c|c|c|c|}
\hline & 2017 Actual & $2018-19$ & $2020-21$ & $2022-25$ & $2026-31$ \\
\hline LNG tank & 81 & & 60 & 80 & 120 \\
(accumulated) & $(1,147)$ & $(1,147)$ & $(1,207)$ & $(1,287)$ & $(1,407)$ \\
\hline Private tank $^{* *}$ & - & 56.5 & 40 & - & - \\
(accumulated) & $(96.5)$ & $(153)$ & $(193)$ & $(193)$ & $(193)$ \\
\hline Sub-Total & 81 & 56.5 & 100 & 80 & 120 \\
(accumulated) & $(1243.5)$ & $(1,300)$ & $(1,400)$ & $(1,480)$ & $(1,600)$ \\
\hline Storage rate & $15 \%$ & $17 \%$ & $18 \%$ & $20 \%$ & $18 \%$ \\
\hline
\end{tabular}

Note: * KOGAS $5^{\text {th }}$ storage tank included, ${ }^{34}$ but Tongyoung storage's satellite base Aewol storage capacity is excluded; ** private firm's storage tanks: Boryung LNG terminal \& POSCO's self-owned facility (already construction approved).

Source: MOTIE, April 2018.

Table 11: Supply facility investment plan (Trillion won)

\begin{tabular}{|l|c|c|c|c|c|c|c|}
\hline & $2017-19$ & $2020-22$ & $2023-25$ & $2026-28$ & $2029-31$ & & Sub-Total \\
\hline $\begin{array}{l}\text { Production } \\
\text { Facility }\end{array}$ & 0.8891 & 0.8033 & 1.3416 & 0.7242 & 0.4581 & & 4.2163 \\
\hline Supply Pipe & 0.6799 & 0.8258 & 0.0518 & - & - & & 1.5575 \\
\hline Sub-Total & 1.5690 & 1.6291 & 1.3934 & 0.7242 & 0.4581 & & 5.7738 \\
\hline
\end{tabular}

Source: MOTIE, April 2018.

Here it is worth noting that the $13^{\text {th }}$ gas plan has laid down the structure of anatural gas supply and demand discussion council to be set up by MOTIE, KOGAS and direct LNG importers in Korea. ${ }^{35}$ This council will be composed of two divisions, one for supply and demand and the other for infrastructure. Regular meetings will be held in March and October every year. MOTIE has indicated that an MOU will be signed by the participants in the first half of 2018, and MOTIE's inclusion in the MOU will represent the state's coordination or intervention for the gas supply. However, the set-up of this council obscures MOTIE's dilemma in making the final decision as to whether the KOGAS monopoly on LNG imports must be stopped, giving more freedom for direct LNG imports by IPPs.

Direct imports of LNG by IPPs has been a very sensitive issue. The Myung-bak Lee administration (2008-12) opened the door for direct LNG imports by IPPs in January 2008, with an initiative by the Ministry of Knowledge and Economy (MKE, and now MOTIE) which revised the city gas business law/regulation to allow the private sector to enter into the LNG import and wholesale business. Based on this revised regulation, the private sector's LNG importers could re-sell the imported LNG to IPPs. In July 2013 (in the first year of the Geun-hye Park administration) the registration conditions for the LNG importers were eased. Previously, the priority was given to the larger capacity of 30 days storage capacity or $100,000 \mathrm{kl}$, but the revised regulation allowed the 30 days storage capacity to be accepted. (The IPPS were responsible for this storage.) Finally, in June 2016, the Korean government approved the gradual opening of gas imports and the wholesale market to the private sector by

\footnotetext{
${ }^{34}$ In late September 2017, Kogas has chosen Dangjin based Seokmoon state industrial complex as the priority negotiation party for the 5th LNG storage base. According to the $12^{\text {th }}$ gas supply and demand plan announced in 2015, by 2031 MOTIE aims at constructing a total of 10 storage tanks, with capacity of $200,000 \mathrm{kl}$ each, and as the first stage work, 4 tanks will be completed by 2023. The remaining six tanks will be completed by adding two tanks in 2025, 2027 and 2029 respectively. MOTIE exploring the option of utilising the base as Asia's LNG hub. See,"천연가스수급안정, LNG 5 기지가책임진다”, 에너지신문,January 5, 2018.http://www.energy-news.co.kr/news/articleView.html?idxno=52341

${ }^{35}$ Andrew Walker, "Gas demand to ebb and flow in South Korea", Interfax Natural Gas Daily, April 10, 2018, p. 5.
} 
$2025 .{ }^{36}$ Since the 9 mtpa supply contracts with Qatar and Oman will expire in 2024, the status of the KOGAS LNG supply monopoly will be fundamentally affected if this volume is available to be contracted by KEPCO's Gencos and private sector players. As discussed later, if the Korean government decides to accept the $10 \mathrm{bcm} / \mathrm{y}$ (or $7 \mathrm{mtpa}$ ) pipeline gas supply via the Russia-DPRKROK gas line or the Yellow Sea gas line, the LNG supply monopoly status of KOGAS will be virtually sustained and it will introduce more options for the gas supply for the Korean Peninsula during the next decade.

Based on the $8^{\text {th }}$ electricity and $13^{\text {th }}$ gas plans, it is clear that renewable energy and natural gas will have a greater share in the generation mix in terms of installed capacity. Strictly speaking, however, top priority has been given to renewable energy, which would account for $33.7 \%$ of installed capacity in 2030 - up from $9.7 \%$ in 2017, while the share of natural gas is expected to be $18.8 \%$, coal $36.1 \%$ and nuclear power $23.9 \%$. The $8^{\text {th }}$ electricity plan halved its target for LNG from $37 \%$ to $18.8 \%$ of Korea's power mix in its latest outlook on the sector. ${ }^{37}$ It was a very disappointing compromise.

Nonetheless, Wood Mackenzie gave a relatively positive verdict saying that although President Moon may not have delivered on his electoral promise to substantially increase the share of gas in the overall generation mix, he has successfully laid the foundations for gas to take centre stage in South Korea's future energy mix. It projected that by 2030 the share of renewable in power generation mix will be only $15 \%$, rather than $20 \%$. The shortfall will be covered by gas and by 2031 gas demand will reach $42 \mathrm{mt}$, around $2 \mathrm{mt}$ higher than the government's target. ${ }^{38}$ Interestingly, Bernstein projected that LNG demand will increase from $36 \mathrm{mtpa}$ to $46 \mathrm{mtpa}$ by 2030 , which is an increase of $30 \%$ or around a $2 \%$ CAGR (compound annual growth rate) growth rate. ${ }^{39}$

Despite the increased role of renewables, South Korea's power generation mix will remain dominated by nuclear and thermal coal, which will still account for $60 \%$ of electricity in $2030 .{ }^{40}$ MOTIE has said that it is aiming to raise consumption taxes on thermal coal by 6 Korean won $(\$ 0.0055)$ per kilogram from April 2018 and to work on other ways to cap coal power generation and to help power generators switch to gas. Considering MOTIE's strong preference for coal in the power generation mix, the switch from coal to gas will be a gradual and tedious process.

\section{Stern Reality of LNG for Power in Korea}

In a 2016 article in the IAEE ${ }^{41} \mathrm{KEEI}$ researcher Dr. Jeong argued that even though South Korea has a strong motivation to import shale gas from the U.S. to diversify its LNG portfolio and weaken its energy import dependency, it is possible that its willingness to do so could be weakened by falling oil prices and the decreasing operating rate of LNG power plants.

\footnotetext{
36김진 철, “눈앞의달콤함천연가스직수입...고민에빠진정부”, 에너지타임즈, April 9, 2018.

http://www.energytimes.kr/news/articleView.html?idxno=43907 ; https://www.platts.com/latest-news/natural-gas/seoul/s-koreato-allow-buyers-to-bypass-kogas-import-27606159 ; http://www.koreaherald.com/view.php?ud=20160614000953

${ }^{37}$ Andrew Walker, "South Korea reins in future LNG demand", Interfax Natural Gas Daily, January 5, 2018, p. 5.

${ }^{38} \mathrm{https}$ ://www.Ingindustry.com/liquid-natural-gas/06042018/wood-mackenzie-provides-an-analysis-of-the-latest-south-koreannatural-gas-supply-plan/

${ }^{39}$ Bernstein, "Global LNG : From feast to famine. The new global cycle begins". April 16, 2018, p. 14. https://www.bernsteinresearch.com/brweb/view.aspx?eid=q3UfCK6kwnJrgwINRAFus1\%2fvlpUB5ryGQsaF2Z7uSm4bUQoRrr7 UkkSym3Dqzqku

40Jane Chung, "South Korea plans shift to renewable, but coal, nuclear to remain strong", December 14, 2017. https://www.reuters.com/article/us-southkorea-energy-policy/south-korea-plans-shift-to-renewables-but-coal-nuclear-to-remainstrong-idUSKBN1E80FZ; Charles Lee, "South Korea unveils power mix plan for 2030 focused on renewable, LNG", Platts, December 14, 2017. https://www.platts.com/latest-news/natural-gas/seoul/s-korea-unveils-power-mix-plan-for-2030-focused$\underline{27897602}$

${ }^{41}$ JeongJikhan, "The Obstacles to South Korea's Willingness to Import Shale Gas from the US", IAEE Energy Forum, Fourth Quarterly 2016, pp. 25-26.
} 
The paper argued that South Korea had a strong willingness to diversify its LNG import portfolio and reduce its LNG import price in pursuit of energy security. In particular, according to the 2012 MOTIE announcement, the South Korean government planned to import shale gas from the U.S., even if the oil price is more than $\$ 80 /$ barrel. In order to decrease dependency on a single vendor, South Korea will limit the share of imports of U.S. shale gas to $20 \%$ of its total gas imports by 2020 . However, the LNG import price in South Korea is mainly linked to the Japanese Crude Cocktail (JCC). Therefore, if the oil price is less than $\$ 80 / \mathrm{barrel}$ in the future, the price of shale gas imported from the U.S. will lose cost-competitiveness with LNG imported from other countries such as Qatar. If the recent fall in oil prices continues until 2020, South Korea's motivation to import shale gas from the U.S. will likely be considerably weakened. ${ }^{42}$

Dr Jeong's paper explained why the role of LNG for power generation in Korea was shrinking. South Korea's wholesale electricity market is a cost-based mandatory pooled system; therefore, all power plants, including LNG power plants with an installed capacity of more than $20 \mathrm{MW}$, must take part in the pool and bid the total amount of power generation. The actual amount of power generation by each plant is determined by merit order and the total amount of electricity demand. However, due to an increase in the amount of bidding from base-load generation, including coal and nuclear power generation, from 349.5 billion $\mathrm{kWh}$ in 2014 to 362.4 billion $\mathrm{kWh}$ in 2015 , the amount of power generation from LNG power plants decreased from 106.4 billion kWh in 2014 to 113.3 billion kWh in 2015.43

The South Korean wholesale electricity market price (= System Marginal Price [SMP]) is determined by the power generation cost of marginal power plants. The LNG power plants have mostly played as marginal power plants, but their share of this marginal power plant group decreased from $94.9 \%$ in 2014 to $90.2 \%$ in 2015. Furthermore, the LNG power plants' heat per unit price has decreased from $78,662 \mathrm{Won} / \mathrm{Gcal}$ in 2014 to $59,910 \mathrm{Won} / \mathrm{Gcal}$ in 2015 due to falling oil prices. At the same time, SMP also decreased from $142.26 \mathrm{Won} / \mathrm{kWh}$ in 2014 to $101.76 \mathrm{Won} / \mathrm{kWh}$ in 2015. As a result, operating rates of LNG power plants and their profitability have fallen from 2014 until $2016 .{ }^{44}$

The business environment for IPPs in Korea during 2015-16 was very depressing. In September 2015, during the parliament hearings in Korea, it was revealed that the financial status of Gencos depending on LNG, whether under KEPCO or IPPs, was deteriorating. The operation rate of LNGbased Gencos was reduced from $63.2 \%$ in 2012 to $48.5 \%$ in 2014.The operating profit of KOEN (Korea South-east Power Co) was 12.2\%, six times higher than the $2.1 \%$ of KOSPO (Korea Southern Power (Co) because KOEN's LNG dependence was only 3.9\%, while KOSPO's was $55.5 \% .{ }^{45}$ The operating profit of KEPCO Gencos increased substantially in the third quarter of 2016, but LNG-based private sector IPPs,_S-Power (Samcholly), Dongducheon Power, Pocheon Power and Pyeongtaek Energy Services all recorded operating losses. ${ }^{46}$ Newly operational coal-fired plants and nuclear plants left continuously shrinking room for LNG-based power plants.

In March 2017, Electricity Times reported that due to the high power reserve rate and the declining operational rate, IPPs were not in a position to recover the minimum margin from operations. It said that three IPPs - POSCO Energy, SK E\&S, and GS EPS- were likely to stay in the black, but that SPower (Samcholly), Dongducheon Power, and Pocheon Power, which recently entered the market, were expected to experience losses. ${ }^{47}$ The business environment for private IPPs was getting worse. ${ }^{48}$

\footnotetext{
${ }^{42}$ Ibid.

${ }^{43}$ lbid.

${ }^{44}$ lbid.

45“LNG 발전애물단지전락, 회생대책시급”, 가스신문 (Gas News), September 10, 2015.

46“민간발전사-발전공기업, 빈익빈부익부양극화현상심화”, 건설경제신문, November 21, 2016

47“탈원전', ‘환경급전’도민간발전사엔 '그림의떡'” (Electricity Times, March 27, 2017).

http://www.electimes.com/article.php?aid=1490623619143062002. For S-Power, see http://s-power.com/intro. For
} 


\subsection{Introducing verycompetitively priced LNG is the solution}

Without a fundamental change in the government's preference for coal and nuclear, the prospects for IPPs based on LNG supply are not promising or encouraging. Nonetheless IPPs are hoping the turnaround will be made - the Moon administration has given a modest expectation of a revival of gas for the power business. The core point is whether KOGAS and Korean IPPs can mobilize the most competitively priced LNG supply. Korea alone will have difficulty in securing the LNG supply source with an optimal price, so that LNG cooperation with Japan and China will be very important.

According to the IEA's World Energy Outlook 2017, global gas trade volume in 2016 was $706 \mathrm{bcm}$, of which $39 \%$ was shipped by LNG, and the volume in 2040 will reach $1,230 \mathrm{bcm}$, of which $59 \%$ will be shipped by LNG. ${ }^{49}$ The dominant role of pipeline gas in global gas trade will be taken by LNG. There is no sign of any slow-down in global LNG demand expansion. Bernstein's new report on Global LNG trends projected that there will be a 60 mpta gap in LNG supply by 2025 and a 200 mpta gap by 2030 which can only be filled by new projects. Annual LNG demand outpaces supply in 2022-23. Given that it takes 5 years to completea project, steps will need to be taken before 2020 to cover the $60 \mathrm{mpta}$ supply gap, and a further 140 mpta will be needed between 2020 and 2025 to ensure markets are adequately supplied. ${ }^{50}$ Without timely prepration, the growing appetite for LNG use in the emerging economies will make a rise in the LNG price in the coming decade inevitable.

China will play a very important role in this LNG demand expansion. In December 2017, shipping data in Thomson Reuters Eikon ${ }^{51}$ indicated that China became the world's second-biggest importer of LNG in 2017 as it overtook South Korea. The data shows that China's imports of LNG will have risen by more than $50 \%$ in 2017 compared with 2016 to around $38 \mathrm{mt}$. Import-dependent Japan and South Korea will have taken around $83.5 \mathrm{mt}$ and just over $37 \mathrm{mt}$ by the end of the year, respectively. This is a huge boost to Asia's emerging spot market as Chinese buyers rely much more on short-term purchases to meet their needs than their counterparts in Japan and South Korea. ${ }^{52}$ Longer term, Bernstein argued that the China government remains committed to raising gas demand to $10 \%$ of the energy mix by 2020 , which represents a consumption of $312 \mathrm{bcm}$. This should mean double digit gas growth for the remainder of the decade. Bernstein's projection is that China's LNG imports will grow from $36 \mathrm{mpta}$ (2017) to $46 \mathrm{mpta}$ by 2019 and to $115 \mathrm{mpta}$ by $2030^{53}$ making China the key player for LNG price setting during the next decade.

If Asian gas consumers have a political will to introduce a competitively priced gas supply source by forming a gas consumer alliance, there is a good opportunity to prepare a back-up plan in preparation for LNG price rebound during the next decade. If Korea's superb EPC (Engineering, Procurement and Construction) capacity is combined with the abundant sleeping sovereign funds from China, a new

Dongducheon Dream Power, see http://www.iddp.co.kr/. For Pocheon Power, see

http://www.pocheonpower.com/front/korean/company/index.

${ }^{48}$ http://www.cnews.co.kr/uhtml/read.jsp?idxno=201611181206186360239;

http://www.gasnews.com/news/articleView.html?idxno=70649

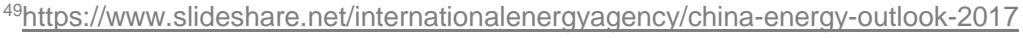

${ }^{50}$ Bernstein, "Global LNG: From feast to famine. The new global cycle begins". April 16, 2018.

https://www.bernsteinresearch.com/brweb/view.aspx?eid=q3UfCK6kwnJrgwINRAFus1\%2fvlpUB5ryGQsaF2Z7uSm4bUQoRrr7 UkkSym3Dazqku

${ }^{51}$ https://financial.thomsonreuters.com/en/products/tools-applications/trading-investment-tools/eikon-trading-software.html

${ }^{52}$ Henning Gloystein, "China becomes world’s No. 2 LNG importer in 2017, behind Japan”, Reuters, December 26, 2017 https://www.reuters.com/article/us-china-Ing/china-becomes-worlds-no-2-Ing-importer-in-2017-behind-iapan-idUSKBN1EK09C ${ }^{53}$ Bernstein, "Global LNG: From feast to famine. The new global cycle begins". April 16, 2018, p. 14.

https://www.bernsteinresearch.com/brweb/view.aspx?eid=q3UfCK6kwnJrgwINRAFus1\%2fvlpUB5ryGQsaF2Z7uSm4bUQoRrr7 UkkSym3Dqzaku 

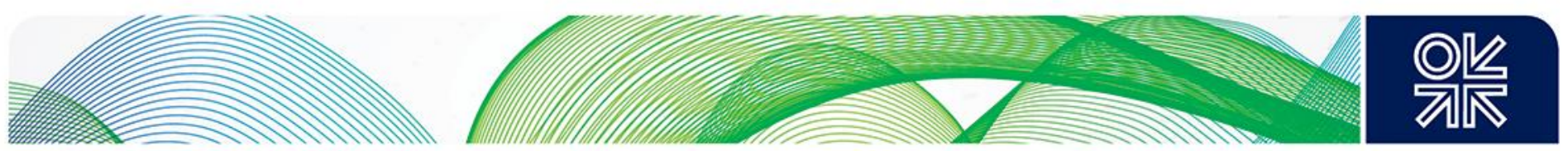

model in global LNG supply can be introduced. This is a kind of blue ocean strategy ${ }^{54}$ which could revolutionise the way global LNG supply structure has been developed and is evolving.

For example, the conversion of flaring gas into LNG could be an excellent target. According to data released by the Global Gas Flaring Reduction Partnership (GGFR), a World Bank-led organization comprised of oil companies, governments, and international institutions working to reduce gas flaring, $141 \mathrm{bcm}$ of natural gas was estimated flared in 2013,145 bcm in 2014 and $147 \mathrm{bcm}$ in 2015. Russia remains the world's largest gas flaring country, flaring about $21 \mathrm{bcm}$ annually, followed by Iraq (16 $\mathrm{bcm})$, Iran $(12 \mathrm{bcm})$, the United States $(12 \mathrm{bcm})$, and Venezuela $(9 \mathrm{bcm}) .{ }^{55}$ The World Bank reports that between 150 and $170 \mathrm{bcm}$ of gases are flared or vented annually, an amount valued at about US\$ 30.6 billion, equivalent to one-quarter of the United States' annual gas consumption or $30 \%$ of the European Union's. ${ }^{56}$

The most ideal way to introduce a very competitively priced LNG supply for Korea and the Northeast Asian region lies in the model of combining the Korean and Japanese liquefaction-related EPC speciality with China's financing capacity together with the large market for LNG supply. Assuming that flaring gas is the feedstock for LNG, conversion will incur reasonable cost. A minimum of one $6 \mathrm{mtpa}$ train from both Nigeria and Iraq can provide a total of $12 \mathrm{mtpa}$ of LNG for Northeast Asian gas consumers, that is, Korea, Japan and China. Successful implementation would open the door for the duplication of the pilot project and if the total volume can reach to the scale of 24-36mtpa it would provide Asian gas consumers with a comfortable cushion that could stabilize the volatile price trend in the coming decade. The pre-requisite is that a very specially rated loan from gas consumer countries' sovereign funds or their policy banks for the LNG plant development should be provided to ensure the minimum cost of LNG production. The unprecedented LNG cooperation among the three countries would usher in a new era of LNG cooperation and could give fresh guidance to many emerging economies on how to take the necessary steps.

At the moment, however, the Moon Jae-In administration's priority is not given to the development of overseas gas supply sources with price competitiveness, but to the investigationinto careless management and wrongdoings by KNOC, KOGAS and KORES (Korea Resources Corp) with regard to overseas investment during the Lee Myung-Bakadministration. ${ }^{57}$ Active overseas oil and gas investment looks very unlikely until this investigation process is cleared. In this situation, the northern energy policy looks very likely to be the new administration's first priority.

\section{The Moon Jae-In administration's northern energy policy and its implications for pipeline gas and LNG imports}

On June 26, 2017, the President's Office instructed that a Presidential Committee

on Northern Economic Cooperation (PCNEC) should be set up to supervise northern economic cooperation initiatives. In pushing ahead with co-operation projects across nine sectors (gas, railways, ports, power generation, North Pole Route, shipbuilding, agriculture, fisheries, and industrial complex) simultaneously, PCNEC is placing a high priority on the gas business. ${ }^{58}$ According to an MBN report, KOGAS is being requested by the Russian government to make an investment in Sakhalin offshore

\footnotetext{
${ }^{54}$ https://en.wikipedia.org/wiki/Blue Ocean Strategy

${ }^{55}$ http://www.worldbank.org/en/news/press-release/2016/12/12/new-data-reveals-uptick-in-global-gas-flaring

${ }^{56}$ http://large.stanford.edu/courses/2016/ph240/miller1/docs/emam.pdf

${ }^{57}$ In a meeting held at Parliament, MOTIE director responsible for resources development strategy confirmed the investigation

on the previous administration's resource diplomacy related wrongdoing will not be an easy job,

See,http://www.energytimes.kr/news/articleView.html?idxno=44172

${ }^{58} \mathrm{http}$ ://www.bukbang.go.kr/bukbang en/about pr/about $\mathrm{pr} /$
} 

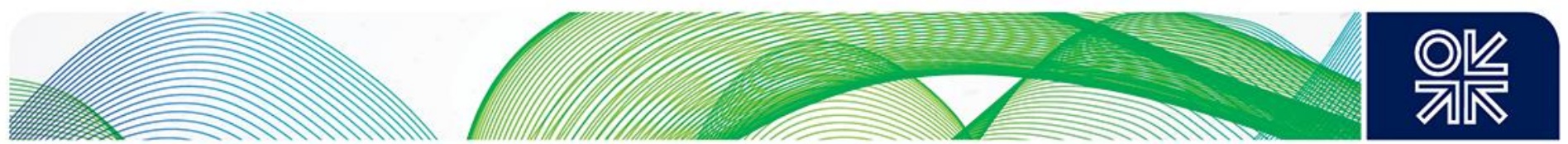

and Arctic onshore gas developments (Arctic LNG) and to increase the LNG supply to Korea. KOGAS is reviewing the possibility of increasing the import volume from the current $1.5 \mathrm{mtpa}$ to $5.0 \mathrm{mtpa} .{ }^{59}$

In an interview with Energy Economy News (EEN), PCNEC's chairman Young-Kil Song said that Korea is reviewing the option of Arctic LNG 2 participation, as demonstrated by the visit of a Korean delegation including KOGAS, Hyundai Engineering and DSME (Daewoo Shipping and Maritime Engineering) to Sabetta on the Yamal Peninsula in late January 2018.60 KOGAS is studying LNG imports, Hyundai Engineering is exploring the possibility of port facility development, and DSME is evaluating the possibility of securing additional ice-breaking LNG tanker construction. As Korea's equity participation in Arctic LNG 2 may be affected by US sanctions against Russia, Korea has to check the legal aspects of US sanctions. ${ }^{61}$ EEN said that on January 29, when the Korean delegation visited Sabetta, Novatek's CEO Leonid Mikhelson asked the Korean government to take part in the Arctic LNG 2 development. The dilemma the Korean government is facing is that to secure more ice-breaking LNG tanker construction for DSME, Korea's equity participation in Arctic LNG 2 and consequently LNG imports from there are a kind of pre-requisite. On top of this, Korean public opinion on Korean government investment in overseas gas development is not so favourable yet, and strengthened US sanctions against Russia are another major obstacle. ${ }^{62}$ Although the Koreanauthorities are keen on participating in the Arctic LNG 2 project, they cannot completely ignore the US sanctions against Russia.

However, the heavy-handed US stance on revising the FTA deal between the US and Korea may offer an excuse for Korea to use the alternative card of US LNG imports. On January 30, 2018, Choi Won-mok, a law professor at EwhaWomans University, said Korea could move to impose higher tariffs on US LNG. His argument was that South Korean companies should consider filing a complaint with the US Court of International Trade over U.S. safeguard measures, noting that filing a case against Washington at the World Trade Organization (WTO) has limitations. His point was that "If South Korea prevails in the trade case at the WTO, there is no other choice but to retaliate under the approval of the WTO if the US does not respect the verdict". ${ }^{63}$ Currently, South Korea imposes no tariff on US LNG under their bilateral free trade deal, except for a $2 \%$ tariff during October-March every year, according to the Korea Customs Service. The first shipment of US shale gas arrived in South Korea in 2017 under a 2012 agreement between KOGAS and Cheniere Energy, which called for KOGAS to import 2.8 mtpa of LNG until 2036. KOGAS estimated its annual imports to be worth $\$ 1.0$ billion. ${ }^{64}$

Separately from the initiative towards Russia, the Korean government has begun to explore ways to restore energy sector cooperation between Korea and China. During President Moon's visit to China in December 2017, both KOGAS and CNPC signed a gas cooperation agreement, and the focus will be on gas trading, LNG storage tank construction, LNG terminal pilot operation and training, the improvement of Asian premium payment, and a joint effort for Northeast Asian gas market development. In addition, KOGAS has discussed the strengthening of technology cooperation in the overseas resources development sector with SINOPEC and the Beijing Gas Group, and LNG trading cooperation with CNOOC. 65

\footnotetext{
59“러시아가스최대 500 만톤도입검토... 한러기업협의회가동”, MBN News, December 6, 2017.

${ }^{60}$ Argus FSU Energy, December 14, 2017, pp. 5-9; Interfax Russia \& CIS Oil and Gas Weekly, December 7-13, 2017, pp. 5-15; James Henderson, "Russian LNG : Progress and delay in 2017", OIES Energy Insight 8, March 2017.

https://www.oxfordenergy.org/wpcms/wp-content/uploads/2017/03/Russian-LNG---Progress-and-delay-in-2017-OIES-EnergyInsight.pdf

${ }^{61} \mathrm{http}: / / \mathrm{m} . \mathrm{ekn} . \mathrm{kr} /$ section view.html?no=340417\# enliple (January 30, 2018)

${ }^{62}$ http://www.ekn.kr/news/article.html?no=342209(February 6, 2018); http://www.ekn.kr/news/article.html?no=342213 (February

6. 2018)

63 "Korea should consider restricting imports of US LNG: scholar", Yonhap News, January 30, 2018

http://www.koreaherald.com/view.php?ud=20180130001019

${ }^{64} \mathrm{Ibid}$.

${ }^{65}$ http://www.energy-news.co.kr/news/articleView.html?idxno=51985 (in Korean)
} 
According to MOTIE's website, on December 14, 2017, MOTIE and NEA (National Energy Administration) under the NDRC (National Development and Reform Commission) signed an energy sector cooperation MOU and agreed to cooperate in the sectors of power transmission line connection, natural gas trading, new energy business and renewable energy, and new energy technology. On top of this, both sides agreed to set up a director general level consultation body to promote energy sector co-operation. ${ }^{66}$ At the follow-up meeting, on May 29, 2018 the first KoreaChina Energy Cooperation Dialogue was held in Seoul. ${ }^{67}$

A big question is whether and when the Seoul authorities will make an official response to CNPC's proposal to construct the Yellow Sea gas pipeline to KNOC. ${ }^{68}$ Power of Siberia (POS) 1 gas will arrive at Bohai Bay in December 2019, ${ }^{69}$ and the extension of the POS 1 gas supply to Shanghai via Shandong and Jiangsu province will be a hot issue soon because the Bohai Bay gas market alone cannot absorb the $38 \mathrm{bcm} / \mathrm{y}$ capacity of POS 1 . Gas will be supplied from the Chayanda gas field (25 $\mathrm{bcm} / \mathrm{y}$ ) and Gazprom intends to accelerate Kovykta gas production and its link with POS 1 by late $2022^{70}$, to cover the remaining $13 \mathrm{bcm} / \mathrm{y}$. This issue is related with the sustaining of Gazprom's pipeline gas export monopoly. Strictly speaking, the $25 \mathrm{bcm} / \mathrm{y}$ of Chayanda gas will have no difficulty in coping with competition from US LNG in the Bohai Bay area, but the $13 \mathrm{bcm} / \mathrm{y}$ of Kovykta gas will not be competitive enough to move into the Jiangsu and Shanghai gas market.

If a consensus on constructing the Yellow Sea gas pipeline between Shandong's Weihai and Korea's Inchon or Pyeongtaek can be reached by CNPC, it will find a new gas market for the East Siberia gas from the two giant gas fields that can be comfortably protected within the boundary of the Bohai Bay gas market and would also open the door for Russia-China-Korea gas pipeline cooperation. In parallel with the Yellow Sea gas pipeline development, if a string of storage tank farms could be constructed in Shandong province in China and Kyonggi province in Korea, it would allow LNG swaps and maximize the benefits of gas cooperation between the two countries.

Separately from this Yellow Sea gas pipeline development option, President Moon Jae-In himself has been mentioning the so-called Pipeline of Peace. During his speech at the Korber Foundation in Berlin on July 7, 2017, he said that,

"The severed inter-Korean railway will be connected again. A train departing from Busan and Mokpo will run through Pyongyang and Beijing, and head towards Russia and Europe. Cooperation projects in Northeast Asia, such as the gas pipeline project connecting the two Koreas and Russia, may also be implemented". ${ }^{71}$

Right after the September 2017 Vladivostok summit between President Putin and President Moon, President Putin said that,

"I would like to say that Russia is still willing to implement trilateral projects with the participation of North Korea. We could deliver Russian pipeline gas to Korea and integrate the power lines and railway systems of Russia, the Republic of Korea and North Korea. The implementation of these

\footnotetext{
${ }^{66} \mathrm{http}: / /$ www.motie.go.kr/motie/ne/motienewse/Motienews/bbs/bbsView.do?bbs cd $\mathrm{n}=2 \&$ bbs seq $\mathrm{n}=155116499$ ${ }^{67}$ http://www.energy-news.co.kr/news/articleView.html?idxno=54066

${ }^{68}$ Paik Keun-Wook(백근욱), "Moon Jae-In Adminsitration's Energy Policy and the Implications of Sino-Russian gas cooperation(문재인정부의에너지정책과중-러가스협력의함의)", Sungkyun China Brief, 권두시평, July 4, 2017, pp. 1928.http://sics.skku.edu/bbs/board.php?tbl=korean\&mode=VIEW\&num=477\&gr id=303020\&; 백근욱, "중-

러에너지협력과미국의트럼프변수 (Sino-Russian Energy Cooperation and US Trump factor)", 국가미래연구원 (IFS), January 31, 2017.http://www.ifs.or.kr/bbs/board.php?bo table=News\&wr id=389Both papersare written in Korean.

${ }^{69} \mathrm{http} / / \mathrm{www}$. gazprom.com/press/news/2018/march/article413496/. For the background of POS 1 development, see KeunWook Paik, "Sino-Russian Gas and Oil Cooperation : Entering into an era of Strategic Partnership", OIES Paper WPM 59, April 2015. http://www.oxfordenergy.org/wpcms/wp-content/uploads/2015/04/WPM-59.pdf

${ }^{70} \mathrm{http}: / /$ www.gazprom.com/press/news/2018/march/article413461/

${ }^{71}$ http://www.koreaherald.com/view.php?ud=20170707000032

https://sputniknews.com/asia/201707081055365078-north-south-korea-russian-gas/
} 
initiatives will be not only economically beneficial but will also help build up trust and stability on the Korean Peninsula". ${ }^{72}$

This confirms Russia's deep interest in pursuing the Russia-DPRK-ROK (R-D-R) pipeline development.

Map 1: Russia's pipeline gas export options/routes for Korean Peninsula

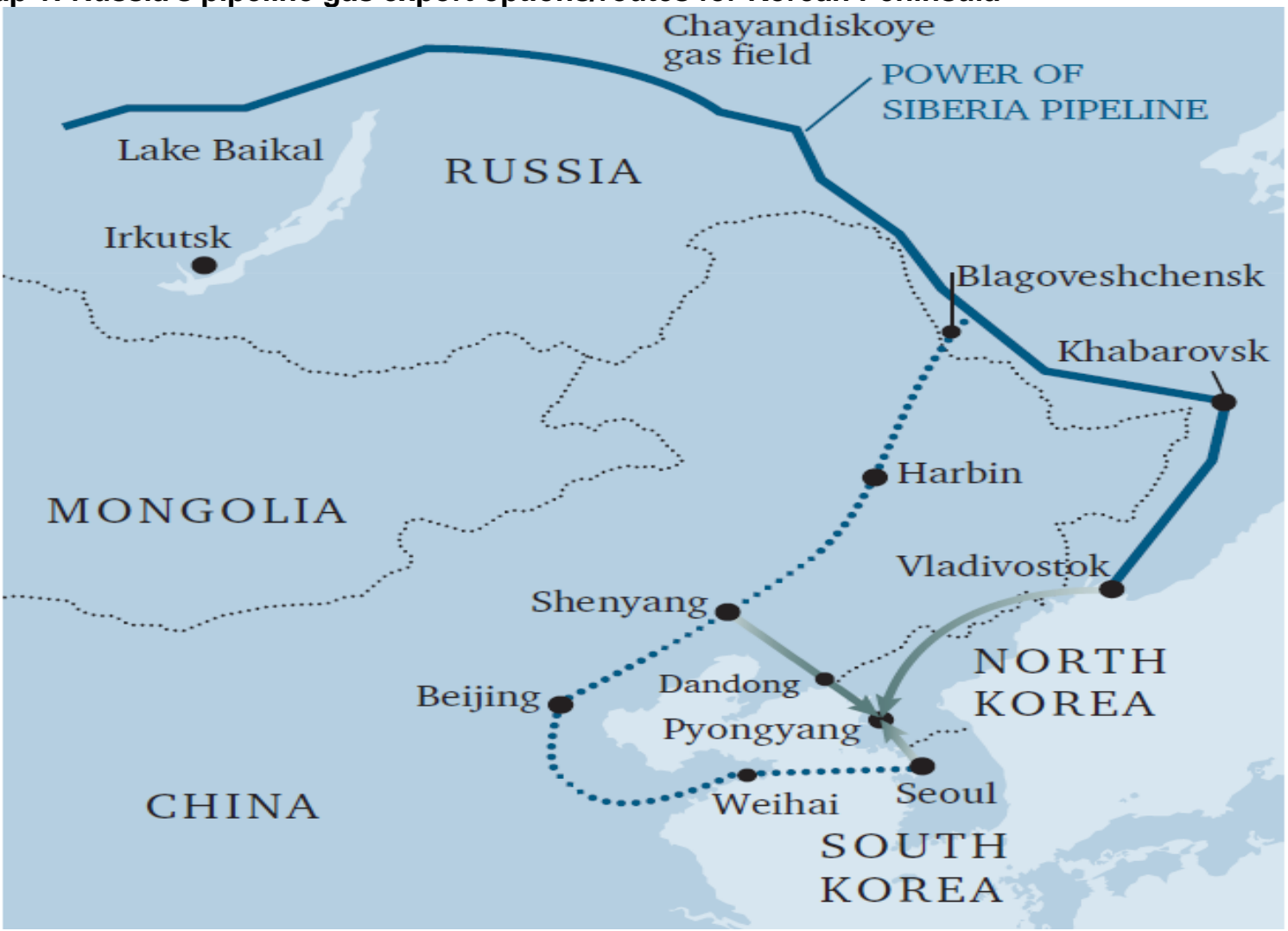

Note: This map was prepared for an in-house seminar at Chatham House (December 2015).

The fierce verbal confrontation between US president Donald Trump and DPRK leader Jong-Un Kim during 2017did not, however, provide President Moon with any chance of reviving the dormant R-DRpipeline concept. If a meaningful compromise on the denuclearization issue is made in the follow-up summit between US President Trump and DPRK leader Jong-Un Kim in Singaporein June $2018^{73}$, after the successful South Korea and North Korea summit on April 27, 2018,74 it is very likely that the R-D-R gas pipeline development project will be the biggest beneficiary of the changed environment.

In this context, the outcome of a US/DPRK summit meeting will be critically important in deciding the fate of pipeline gas options for the Korean peninsula. If the South Korean President Office's green light is given first to the R-D-Rpipeline, it does not necessarily mean the Yellow Sea gas pipeline has to be sidelined. The most ideal situation will be to pursue both pipelines simultaneously. This would affect Korea's LNG import strategy fundamentally, but there are some factors that should be properly reviewed for the development of pipeline gas supply.

\footnotetext{
${ }^{72}$ https://www.globalresearch.ca/statements-of-russias-president-putin-and-south-koreas-president-moon-regarding-northkorea-and-economic-cooperation/5608089

${ }^{73}$ https://www.nytimes.com/2018/03/09/world/asia/moon-jae-in-trump-kim-jong-un.html ; https://www.bbc.co.uk/news/world-uscanada-44339003

${ }^{74}$ http://www.bbc.co.uk/news/world-asia-43914208 ; https://www.thequardian.com/world/live/2018/apr/27/north-and-southkorea-summit-leaders-prepare-for-historic-inter-korean-meeting-live
} 
The main reason for supplying Sakhalin offshore gas for theR-D-R pipeline lies in its price competitiveness. If the $8 \mathrm{bcm}$ of gas from Sakhalin 1 is allocated for China's northeastern province ${ }^{75}$ or for Sakhalin 2's LNG expansion ${ }^{76}$, the remaining gas source for the R-D-R line will be either Sakhalin 3 offshore gas or Kovykta gas through the POS 1 line extension from Blagoveshchensk to Vladivostok. ${ }^{77}$ Delay in production and the high cost of offshore gas development will make it difficult $t$ o justify the economics of Sakhalin 3's offshore gas supply or the extension of Kovykta gas towards the S-K-V (Sakhalin-Khabarovsk-Vladivostok) gas line. ${ }^{78}$ If a political breakthrough is made, however, the R-D-R line will be definitely promoted regardless of the economics of the pipeline development. The R-D-R line will be a politically good gesture, but economically speaking, the delivered gas will not offer good value in terms of price competitiveness. ${ }^{79}$ It may be the minimum price South Korean people have to pay for peace and stability on the Korean Peninsula in the coming decades.

Regardless of the introduction of the R-D-R gas line, the core value of the Yellow Sea pipeline construction lies in the fact that it will help promote both pipeline gas and LNG cooperation in parallel between Korea and China. Assuming that a large-scale LNG storage tank farm development and operation in Shandong province and Kyonggi province will not be taken care of by CNPC and KOGAS exclusively, but will be handled by a Chinese/Korean consortium comprising private entities, the boundary of LNG cooperation between Korea and China could expand significantly. In the long-term perspective, the Yellow Sea pipeline could serve as the first step for a circular gas pipeline connecting the Bohai Bay rim gas market, that is, Liaoning, Hebei and Shandong province, with the unified Korean peninsula. The connection of this Bohai Bay circular gas pipeline with the R-D-R gas piplinewould ensure the removal of the concern about gas supply security under any circumstances.

\section{Conclusion}

In 2012 the IEA review of Korea's energy policy clearly stated that "The previous IEA in-depth review highlighted the lack of a clear, long-term vision for Korea'selectricity and natural gas markets as the greatest challenge facing the government. While the government has maintained its commitment to reform, there has been limitedprogress and the country has faced a series of rolling electricity loadshedding events inthe recent past... The main elements of an electricity market reform programme should include: greater restructuring of the KEPCO and revisiting the design of the wholesale market; and strengthening the independence of the sector regulator to enable fair competition, including the removal of barriers to new entrants and third-party access to network infrastructure, and creating clear roles for publicly owned and private entities. Reform of the electricity market should be accompanied by a complementary programmeof change in the natural gas market. Korea has built significant infrastructure to support the emergence of a natural gas market. A greater element of unbundling of storage, transmission and distribution may be required...KOGAS, the small number of direct importers of natural gas, the thirty city gas companies and other market participants should be encouraged to trade gas amongst themselves across the existing natural gas transmission infrastructure. All large customers should have the option of buying from a source other than KOGAS

\footnotetext{
${ }^{75}$ http://www.gazprom.com/press/news/2017/december/article388463/

${ }^{76}$ Michael Bradshaw, "Russian sanctions slowing progress offshore Sakhalin", Offshore, February 1, 2018.https://www.offshoremag.com/articles/print/volume-77/issue-12/departments/beyond-the-horizon/russian-sanctions-slowing-progress-offshoresakhalin.html

${ }^{77}$ Gazprom has postponed the South Kirinskoye field production timing from 2021 to 2023. https://newsbase.com/commentary/gazprom-unveils-revised-strategy-russian-shelf

${ }^{78}$ http://www.gazprom.com/about/production/projects/pipelines/active/shvg/

${ }^{79}$ During 2002-03 the author strongly recommended the Roh Moo-Hyun Administration to promote the Sakhalin 1 gas supply to the Korean Peninsula in return for DPRK's surrender of nuclear ambition. If a pleasant turnaround is made with regard to DPRK's denuclearization, the unfullfilledsuggestion can serve the purpose for the Korean Peninsula's peaceful settlement. See, Keun-Wook Paik, "Natural gas expansion in Korea", in lan Wybrew-Bond and Jonathan Stern, ed., Natural gas in Asia: Challenge of Growth in China, India, Japan and Korea (Oxford: Oxford University Press, 2002), pp. 201-208.
} 

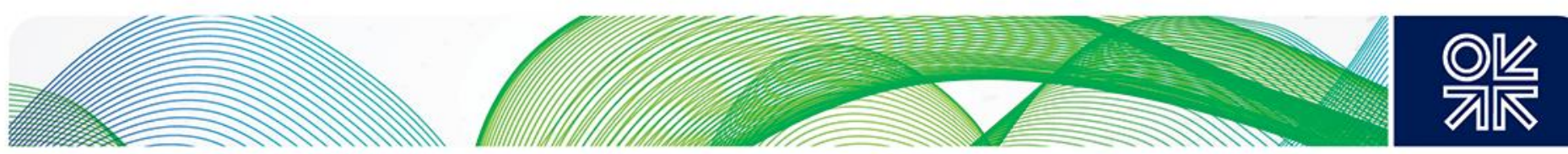

at appropriate market rates. The government should develop and implement policies to allow a wholesale gas market to emerge." 80

What would be the IEA's verdict on Korea's gas sector reform if an updated review was made in 2018? The IEA review team would point out the absence of meaningful reform in both the electricity and gas sector during the Geun-Hye Park administration and would ask whether the Moon Jae-In administration will make a bold and radical reform in both sectors. Strictly speaking, the verdict after the first-year performanceis that the Moon Jae-In adminstration's new energy policy is focused too much on the role of renewable energy in replacing nuclear energy in Korea's energy mix, and the steps taken for gas expansion are at most modest.

It is premature, however, to make a verdict that Korea's gas expansion will not be as promising as the presidential campaign had envisaged. Before making the verdict, the following questions have to be addressed to judge how far Korea's gas expansion will go: First, will the dominant status of KOGAS in LNG supply be sustained? Secondly, will overseas investment in LNG supply development by Korean companies be revived by the government despite the very discouraging performance or absence of activity of both KOGAS and KNOC during the previous administrations? Thirdly, can Korea diversify its LNG supply sources, in particular to include Russia Arctic LNG despite the US and EU sanctions against Russia? Finally, can the US-North Korea summit open the door for Russia's pipeline gas supply for the Korean peninsula? Time will tell the answers. 
Annex 1: Korea's short, mid, long-term LNG supply contracts

\begin{tabular}{|c|c|c|c|c|}
\hline $\begin{array}{l}\text { Producing } \\
\text { Countries }\end{array}$ & $\begin{array}{l}\text { Project } \\
\text { Name }\end{array}$ & $\begin{array}{c}\text { Contract } \\
\text { Volume } \\
(\mathrm{mt} / \mathrm{y})\end{array}$ & $\begin{array}{l}\text { Contract } \\
\text { Period }\end{array}$ & $\begin{array}{l}\text { Delivery } \\
\text { Terms }\end{array}$ \\
\hline \multicolumn{5}{|c|}{ KOGAS Long-term Supply } \\
\hline \multirow[t]{7}{*}{ Indonesia } & Arun & 2.00 & 1986-2007 & DES \\
\hline & Arun & 0.3 & $1992-2007$ & DES \\
\hline & Arun & 2.00 & 1994-2014 & FOB \\
\hline & BontangBadak V & 1.00 & 1998-2017 & FOB \\
\hline & Bontang & 1.80 & $2011-2012$ & FOB \\
\hline & Tangguh & 0.36 & $2011-2012$ & DES \\
\hline & $\begin{array}{l}\text { DonggiSenoro } \\
\text { DSLNG }\end{array}$ & 0.70 & 2015-2028 & FOB \\
\hline \multirow[t]{5}{*}{ Malaysia } & MLNG Dua & 2.00 & 1995-2015 & FOB \\
\hline & MLNG Tiga & 2.00 & $2003-2010$ & DES \\
\hline & MLNG Tiga & 0.79 & $2004-2008$ & FOB \\
\hline & MLNG Tiga & 0.50 & $2005-2008$ & DES \\
\hline & MLNG Tiga & $\begin{array}{c}1.50+\text { Buyer option } \\
0.50 \\
\end{array}$ & 2008-2028 & DES \\
\hline \multirow[t]{2}{*}{ Brunei } & BLNG & 0.70 & $1997-2013$ & DES \\
\hline & BLNG & 1.00 & 2013-2023 & DES \\
\hline Oman & OLNG & 4.06 & $2000-2024$ & FOB \\
\hline \multirow{6}{*}{ Qatar } & Ras Gas & 2.00 & $2012-2016$ & DES \\
\hline & Ras Gas & 2.00 & 2013-2032 & DES \\
\hline & Ras Gas I & 4.80 & 1999-2024 & FOB \\
\hline & Ras Gas I & 1.07 & $2004-2008$ & DES \\
\hline & Ras Gas III & 2.10 & 2007-2027 & DES \\
\hline & Ras Gas II & $2.00+$ mid Term & 2012-2032 & DES \\
\hline Yemen & YLNG & 2.00 & 2008-2028 & FOB \\
\hline Russia & Sakhalin II & 1.50 & 2008-2028 & FOB \\
\hline \multirow[t]{6}{*}{ Australia } & NWS & 0.50 & 2003-2016 & DES \\
\hline & GLNG & $3.00+$ option 0.50 & 2015-2035 & FOB \\
\hline & Prelude & 3.64 & 2013-2038 & DES \\
\hline & Shell & 1.00 & 2013-2016 & DES \\
\hline & Woodside & 2.20 & 2014-2017 & DES \\
\hline & Total & 2.00 & 2014-2031 & DES \\
\hline Egypt & $B G$ & $\begin{array}{c}1.32+\text { Seller option } \\
0.24\end{array}$ & $2008-2016$ & DES \\
\hline Peru & Peru LNG & 0.90 & $2011-2012$ & DES \\
\hline US & Sabine Pass & 2.80 & 2017-2037 & FOB \\
\hline Total & Portfolio & 2.00 & 2014-2031 & DES \\
\hline Shell & Portfolio & 3.64 & 2013-2038 & DES \\
\hline Korea Domestic & Donghae & 0.40 & 2004-2018 & Pipeline gas \\
\hline \multicolumn{5}{|c|}{ Kogas Short \& Mid Term Supply } \\
\hline Malaysia & Petronas & $\begin{array}{l}21 \text { tankers + buyer's } \\
\text { option } 2 \text { tankers }\end{array}$ & $2015-2018$ & FOB \\
\hline Algeria & ENI & 15 tankers & 2014-2017 & DES \\
\hline
\end{tabular}




\begin{tabular}{|c|c|c|c|c|}
\hline Australia & Woodside & $\begin{array}{l}14 \text { tankers }+ \text { seller's } \\
\text { option } 14 \text { tankers }\end{array}$ & 2014-2017 & DES \\
\hline Gas Natural & Portfolio & 0.45 & $2014-2015$ & DES \\
\hline Gazprom & Portfolio & 0.50 & 2013-2014 & DES \\
\hline GDF Suez & unspecified & 1.60 & 2013-2014 & DES \\
\hline GDF Suez & Portfolio & 0.72 & $2010-2013$ & DES \\
\hline $\mathrm{BP}$ & unspecified & 0.72 & $2010-2013$ & DES \\
\hline Total & unspecified & 0.18 & $2010-2012$ & DES \\
\hline \multicolumn{5}{|c|}{ Non-KOGAS Supply } \\
\hline \multicolumn{5}{|l|}{ SK E\&S } \\
\hline Australia & Gorgon LNG & 0.83 & 2017-2022 & DES \\
\hline US & Freefort & 2.20 & 2019-2039 & Tolling \\
\hline \multicolumn{5}{|l|}{ GS Caltex } \\
\hline Australia & Gorgon LNG & 0.25 & 2017-2036 & DES \\
\hline US & Cameron & 0.60 & 2019-2039 & DES \\
\hline \multicolumn{5}{|l|}{ S-Oil } \\
\hline Malaysia & Petronas & 0.70 & 2018-2033 & $? ?$ \\
\hline \multicolumn{5}{|l|}{ K-Power } \\
\hline Indonesia & Tangguh & 0.60 & 2005-2025 & DES \\
\hline \multicolumn{5}{|l|}{ POSCO } \\
\hline Indonesia & Tangguh & 0.55 & 2005-2025 & DES \\
\hline \multicolumn{5}{|l|}{ KOMIPO } \\
\hline Vitol & Portfolio & 0.40 & 2015-2024 & DES \\
\hline \multicolumn{5}{|c|}{ Hanyang Corp } \\
\hline US & Delfin LNG & 1.50 & $? ?$ & \\
\hline
\end{tabular}

Source: KOGAS/Korea Gas Union/author's data base 
Annex 2: Korea's LNG imports by country: 1988-1997 (mtpa)

\begin{tabular}{|l|c|c|c|c|c|c|c|c|c|c|}
\hline & 1988 & 1989 & 1990 & 1991 & 19922 & 1993 & 1994 & 1995 & 1996 & 1997 \\
\hline Indonesia & 1.90 & 2.01 & 2.24 & 2.43 & 2.93 & 4.11 & 5.43 & 4.89 & 5.97 & 6.73 \\
\hline Qatar & & & & & & & & & & \\
\hline Malaysia & & & & 0.06 & 0.06 & 0.29 & 0.29 & 1.04 & 2.57 & 3.93 \\
\hline Oman & & & & & & & & & & \\
\hline Brunei & & & & & & & 0.27 & 0.71 & 0.65 & 0.76 \\
\hline Australia & & & & & & 0.06 & & 0.11 & 0.06 & \\
\hline Egypt & & & & & & & & & & \\
\hline Others & & & & & & & & & & \\
\hline Total & $\mathbf{1 . 9 0}$ & $\mathbf{2 . 0 1}$ & $\mathbf{2 . 2 4}$ & $\mathbf{2 . 4 9}$ & $\mathbf{2 . 9 9}$ & $\mathbf{4 . 4 6}$ & $\mathbf{5 . 9 9}$ & $\mathbf{6 . 7 5}$ & $\mathbf{9 . 2 5}$ & $\mathbf{1 1 . 4 7}$ \\
\hline
\end{tabular}

Source: http://www.kesis.net/sub/subChart.jsp?report id $=7020200 \&$ reportType $=0$

Annex 2.1: Korea's LNG imports by country: 1998-2007 (mtpa)

\begin{tabular}{|l|c|c|c|c|c|c|c|c|c|c|}
\hline & 1998 & 1999 & 2000 & 2001 & 2002 & 2003 & 2004 & 2005 & 2006 & 2007 \\
\hline Indonesia & 6.74 & 7.94 & 6.63 & 4.06 & 5.26 & 5.20 & 5.29 & 5.50 & 5.06 & 3.75 \\
\hline Qatar & & 0.48 & 3.25 & 4.66 & 5.12 & 5.69 & 5.82 & 6.21 & 6.46 & 8.03 \\
\hline Malaysia & 2.85 & 3.04 & 2.53 & 2.18 & 2.40 & 2.80 & 4.64 & 4.69 & 5.55 & 6.16 \\
\hline Oman & & & 1.62 & 3.78 & 3.97 & 4.71 & 4.41 & 4.24 & 5.22 & 4.79 \\
\hline Brunei & 0.54 & 0.70 & 0.85 & 0.59 & 0.77 & 0.61 & 0.84 & 0.59 & 0.85 & 0.59 \\
\hline Australia & & & 0.05 & 0.06 & 0.18 & 0.12 & 0.29 & 0.75 & 0.70 & 0.42 \\
\hline Egypt & & & & & & & & 0.27 & 0.95 & 1.12 \\
\hline Others & 0.06 & 0.12 & 0.30 & & 0.30 & 0.17 & 0.50 & 0.06 & 0.47 & 0.69 \\
\hline Total & $\mathbf{1 0 . 1 9}$ & $\mathbf{1 2 . 2 8}$ & $\mathbf{1 5 . 2 4}$ & $\mathbf{1 5 . 3 2}$ & $\mathbf{1 7 . 9 9}$ & $\mathbf{1 9 . 3 1}$ & $\mathbf{2 1 . 7 8}$ & $\mathbf{2 2 . 3 2}$ & $\mathbf{2 5 . 2 6}$ & $\mathbf{2 5 . 5 7}$ \\
\hline
\end{tabular}

Source: http://www.kesis.net/sub/subChart.jsp?report id=7020200\&reportType $=0$

Annex 2.2: Korea's LNG imports by country: 2008-2016 (mtpa)

\begin{tabular}{|l|c|c|c|c|c|c|c|c|c|}
\hline & 2008 & 2009 & 2010 & 2011 & 2012 & 2013 & 2014 & 2015 & 2016 \\
\hline Indonesia & 3.05 & 3.08 & 5.45 & 7.89 & 7.45 & 5.63 & 5.18 & 3.78 & 4.36 \\
\hline Qatar & 8.74 & 6.97 & 7.45 & 8.15 & 10.28 & 13.35 & 12.85 & 12.44 & 11.88 \\
\hline Malaysia & 6.25 & 5.87 & 4.74 & 4.14 & 4.08 & 4.31 & 3.67 & 3.70 & 3.81 \\
\hline Oman & 4.54 & 4.55 & 4.56 & 4.19 & 4.13 & 4.33 & 3.73 & 3.99 & 4.08 \\
\hline Brunei & 0.74 & 0.53 & 0.79 & 0.76 & 0.77 & 1.14 & 0.72 & 1.23 & 1.40 \\
\hline Australia & 0.40 & 1.31 & 1.03 & 0.79 & 0.83 & 0.62 & 0.84 & 1.95 & 4.69 \\
\hline Egypt & 1.41 & 0.24 & 0.74 & 0.46 & 0.60 & 0.60 & 0.07 & & \\
\hline Others & 2.12 & 3.26 & 7.85 & 10.30 & 8.04 & 9.89 & 10.06 & 6.28 & 3.22 \\
\hline Total & $\mathbf{2 7 . 2 6}$ & $\mathbf{2 5 . 8 2}$ & $\mathbf{3 2 . 6 0}$ & $\mathbf{3 6 . 6 8}$ & $\mathbf{3 6 . 1 8}$ & $\mathbf{3 9 . 8 8}$ & $\mathbf{3 7 . 1 1}$ & $\mathbf{3 3 . 3 6}$ & $\mathbf{3 3 . 4 5}$ \\
\hline
\end{tabular}

Source: http://www.kesis.net/sub/subChart.jsp?report id=7020200\&reportType $=0$ 
Annex 3: Korea's monthly LNG imports price: 1988-2007 (US\$/tonne)

\begin{tabular}{|l|c|c|c|c|c|c|c|c|c|c|}
\hline & 1988 & 1999 & 2000 & 2001 & 2002 & 2003 & 2004 & 2005 & 2006 & 2007 \\
\hline Jan & 180.2 & 132.7 & 215.6 & 279.2 & 223.8 & 259.7 & 263.3 & 329.7 & 438.8 & 497.1 \\
\hline Feb & 180.6 & 135.9 & 227.4 & 280.0 & 221.9 & 268.4 & 265.6 & 339.7 & 458.5 & 458.8 \\
\hline Mar & 169.2 & 128.5 & 241.7 & 282.3 & 213.4 & 271.8 & 268.6 & 327.6 & 419.2 & 458.0 \\
\hline Apr & 190.9 & 135.2 & 247.0 & 279.6 & 207.4 & 263.5 & 280.4 & 350.9 & 456.3 & 451.8 \\
\hline May & 194.6 & 148.5 & 246.7 & 255.9 & 209.0 & 258.4 & 288.4 & 373.8 & 484.7 & 450.7 \\
\hline June & 188.4 & 156.1 & 257.2 & 259.9 & 210.2 & 269.9 & 303.3 & 385.3 & 483.7 & 474.4 \\
\hline July & 183.7 & 154.7 & 269.4 & 246.4 & 213.8 & 275.5 & 307.8 & 407.1 & 510.1 & 470.0 \\
\hline Aug & 166.4 & 175.5 & 267.2 & 245.8 & 225.2 & 264.8 & 318.9 & 434.5 & 512.2 & 516.0 \\
\hline Sep & 153.3 & 180.9 & 269.4 & 247.8 & 238.6 & 261.9 & 333.6 & 426.2 & 498.2 & 500.3 \\
\hline Oct & 157.0 & 192.7 & 285.8 & 252.6 & 247.9 & 254.6 & 336.3 & 493.3 & 521.7 & 506.8 \\
\hline Nov & 140.5 & 197.6 & 285.3 & 243.4 & 251.3 & 259.0 & 347.8 & 428.8 & 468.4 & 527.6 \\
\hline Dec & 132.2 & 207.6 & 279.3 & 227.8 & 249.2 & 258.5 & 329.7 & 434.6 & 494.7 & 589.3 \\
\hline
\end{tabular}

Source: http://www.kesis.net/sub/subChart.jsp?report id=7050100\&reportType $=0$ (accessed from KEEI Energy Data basis website, on December 12, 2017)

Annex 3.1: Korea's monthly LNG imports price: 2008-2017 (US\$/tonne)

\begin{tabular}{|l|l|l|l|l|l|l|l|l|l|l|}
\hline & 2008 & 2009 & 2010 & 2011 & 2012 & 2013 & 2014 & 2015 & 2016 & 2017 \\
\hline Jan & 587.9 & 769.4 & 497.0 & 528.8 & 690.6 & 773.3 & 810.3 & 741.6 & 416.5 & 413.0 \\
\hline Feb & 603.8 & 665.8 & 467.4 & 527.1 & 743.8 & 780.4 & 861.3 & 699.9 & 402.7 & 418.5 \\
\hline Mar & 615.6 & 608.1 & 509.0 & 565.5 & 705.7 & 791.2 & 861.2 & 680.0 & 376.5 & 407.9 \\
\hline Apr & 720.0 & 454.1 & 567.4 & 630.8 & 790.9 & 745.6 & 857.0 & 605.4 & 342.4 & 411.2 \\
\hline May & 696.8 & 398.4 & 578.4 & 630.9 & 826.8 & 759.9 & 854.0 & 494.4 & 311.1 & 432.6 \\
\hline June & 708.5 & 386.5 & 528.6 & 698.0 & 865.1 & 777.2 & 868.4 & 473.3 & 296.5 & 407.9 \\
\hline July & 776.9 & 375.9 & 547.2 & 694.8 & 820.3 & 775.9 & 850.6 & 460.7 & 305.2 & 408.6 \\
\hline Aug & 773.7 & 420.1 & 564.7 & 725.7 & 811.5 & 766.9 & 848.8 & 480.9 & 330.7 & 425.6 \\
\hline Sep & 825.5 & 437.6 & 542.2 & 718.3 & 766.7 & 776.5 & 857.0 & 499.2 & 352.8 & - \\
\hline Oct & 860.2 & 458.7 & 516.9 & 716.1 & 675.4 & 752.4 & 843.5 & 505.0 & 379.2 & - \\
\hline Nov & 870.5 & 475.5 & 511.0 & 703.9 & 672.6 & 757.9 & 828.4 & 494.9 & 388.3 & - \\
\hline Dec & 856.2 & 499.2 & 506.6 & 750.2 & 765.5 & 761.2 & 836.0 & 453.1 & 378.9 & - \\
\hline
\end{tabular}

Source: http://www.kesis.net/sub/subChart.jsp?report id $=7050100 \&$ reportType $=0$

(accessed from KEEI Energy Data basis website, on December 12, 2017) 
Annex 4: Korea's domestic natural gas demand trend (mtpa)

\begin{tabular}{|l|c|c|c|c|c|c|c|c|}
\hline & \multirow{2}{*}{1987} & 1997 & 2002 & 2008 & 2014 & \multicolumn{3}{|c|}{ annual growth rate } \\
\cline { 1 - 4 } & & & & & & $87-14$ & $87-02$ & $02-14$ \\
\hline CG & 0.075 & 5.770 & 11.194 & 15.316 & 18.533 & $22.6 \%$ & $39.6 \%$ & $4.3 \%$ \\
\hline PG & 1.537 & 5.377 & 6.509 & 11.951 & 17.960 & $9.5 \%$ & $10.1 \%$ & $8.8 \%$ \\
\hline Total & 1.612 & 11.147 & 17.703 & 27.267 & 36.493 & $12.2 \%$ & $17.3 \%$ & $6.2 \%$ \\
\hline
\end{tabular}

Note: CG means city gas and PG means power generation

Source: MOTIE, $12^{\text {th }}$ Gas Supply and Demand Plan (2015-2029), announced in December 2015.

Annex 4.1: Long-term natural gas demand projection: 12 ${ }^{\text {th }}$ Plan, 2015- 2029 (mtpa)

\begin{tabular}{|c|c|c|c|c|c|c|}
\hline \multirow[t]{2}{*}{ Year } & \multicolumn{4}{|c|}{ City Gas } & \multirow[t]{2}{*}{$P G$} & \multirow[t]{2}{*}{ Total } \\
\hline & residential & general & industrial & Sub-total & & \\
\hline $2014(\mathrm{~A})$ & 7.174 & 2.947 & 8.412 & 18.533 & 17.960 & 36.493 \\
\hline 2015 & 7.125 & 2.907 & 7.591 & 17.623 & 16.074 & 33.697 \\
\hline 2022 & 8.269 & 3.978 & 10.596 & 22.842 & 11.120 & 33.962 \\
\hline 2029 & 8.686 & 4.575 & 11.911 & 25.171 & 9.480 & 34.651 \\
\hline $15-29$ AG & $1.28 \%$ & $2.98 \%$ & $2.35 \%$ & $2.06 \%$ & $4.17 \%$ & $0.34 \%$ \\
\hline
\end{tabular}

Note: PG means power generation; A means actual; AG means annual growth rate

Source: MOTIE, $12^{\text {th }}$ Gas Supply and Demand Plan (2015-2029), announced in December 2015.

Annex 4.2: LNG storage facilities construction plan (10,000 KI)

\begin{tabular}{|l|c|c|c|c|c|}
\hline & 2014 Actual & $2015-17$ & $2018-19$ & $2020-25$ & $2026-29$ \\
\hline LNG tank & 60 & 201 & 60 & 120 & 80 \\
(accumulated) & $(946)$ & $(1,147)$ & $(1,207)$ & $(1,443.5)$ & $(1,523.5)$ \\
\cline { 1 - 4 } Private tank & - & 60 & 20 & & \\
(accumulated) & $(36.5)$ & $(96.5)$ & $(116.5)$ & & 80 \\
\cline { 1 - 4 } Sub-Total & 60 & 261 & 80 & 120 & $(1,523.5)$ \\
(accumulated) & $(982.5)$ & $(1,243.5)$ & $(1,323.5)$ & $(1,443.5)$ & $20 \%$ \\
\hline Storage rate & $12 \%$ & $17 \%$ & $17 \%$ & $19 \%$ & \\
\hline
\end{tabular}

Note: * private firm's storage tanks : Boryung LNG terminal \& POSCO's self-owned facility; ** Jeju's Ae-wol base storage capacity $(2019,90,000 \mathrm{KI})$ is not included; ${ }^{* * *}$ The accumulated volume of 9.46 million $\mathrm{kl}$ is composed of $3.36 \mathrm{mkl}$ from Pyeongtaek facility, $2.88 \mathrm{mkl}$ from Inchon facility, $2.62 \mathrm{mkl}$ from Tongyoung facility, and $0.6 \mathrm{mkl}$ from Samcheok facility.

Source: $12^{\text {th }}$ Gas Supply and Demand Plan. 